اثر كودهاى زيستى و شيميايى بر برخى صفات فيزيولوزيك، اجزاى عملكرد و عملكرد گياه

\author{
كينوا \\ مهدى اميريوسفى'، محمودرضا تدين ب* و رحيم ابر اهيمى

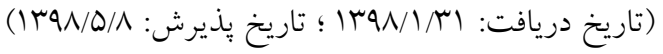

جكيده

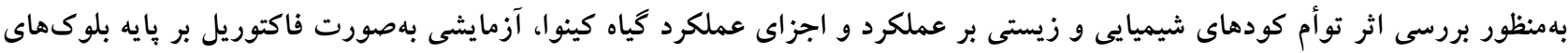

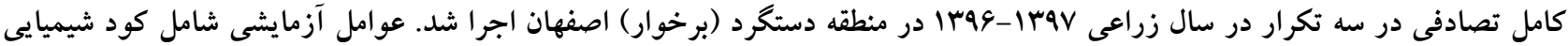

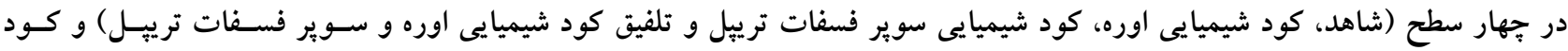

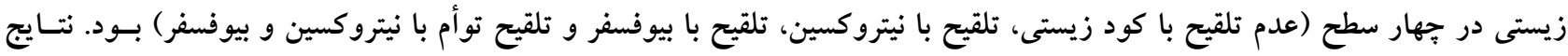

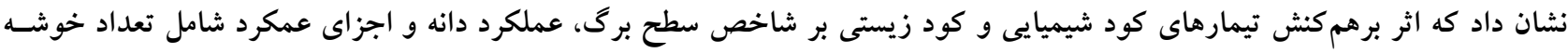

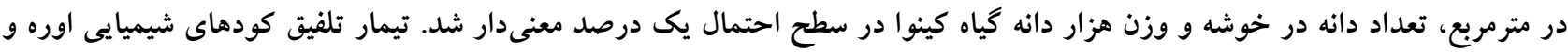

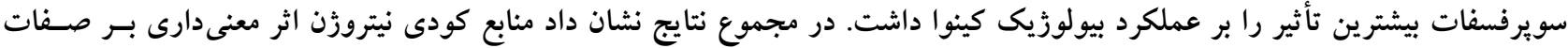

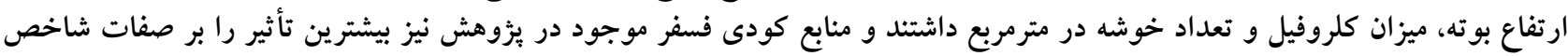

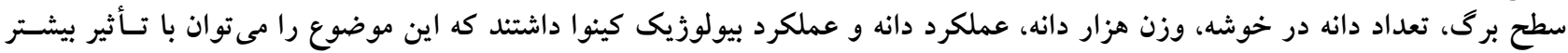

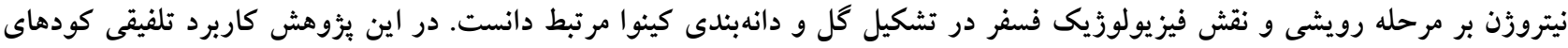

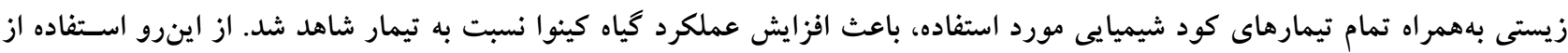

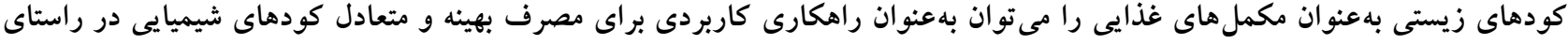

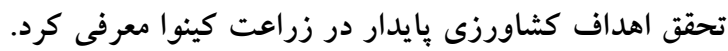

وازههاى كليدى: نيتروزن، فسفر، شاخص سطح برى، عملكرد بيولوزيك، كينوا

او r. بلترتيب دانشجوى دكترى و استاد گروه زراعت، دانشكده كشاورزى، دانشكاه شهركرد، شهركرد

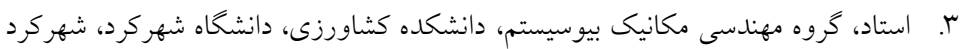

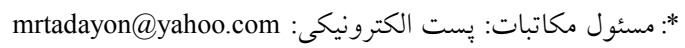




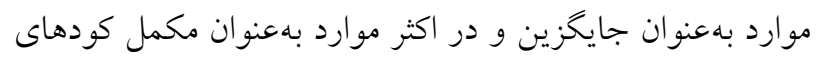

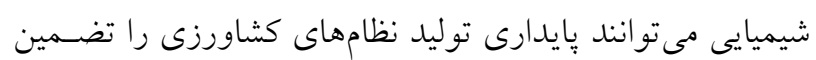

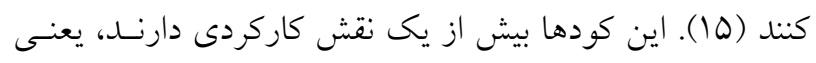

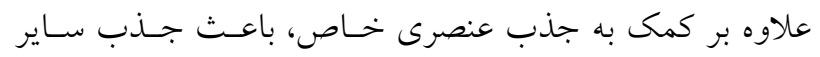

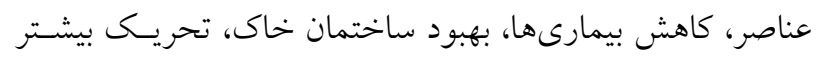

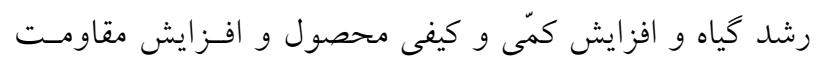

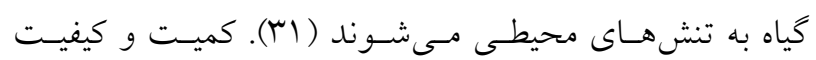

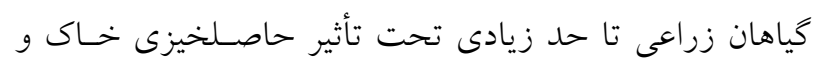

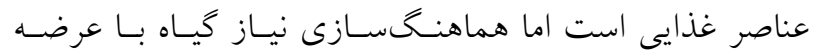

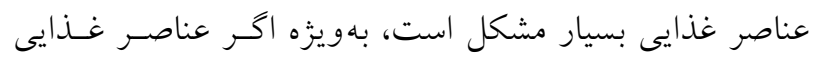

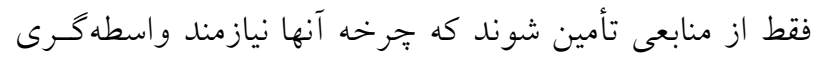

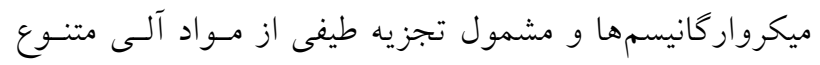

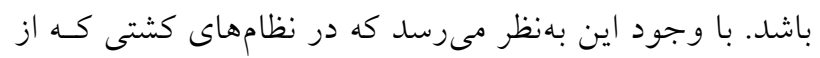

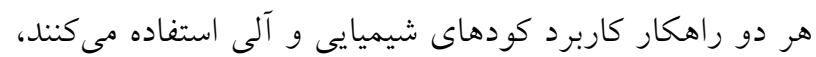
كارايى بهينه استفاده از عناصر غذايى افزايش مى يابــ (م). بنـا

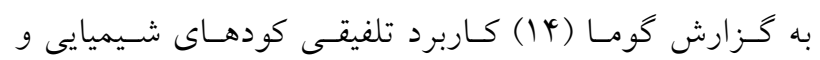
زيستى نيتروزن و فسفر ضمن كـاهش دادن مصـرف كودهـاى دونى

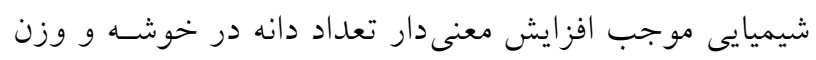

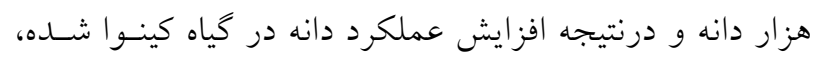

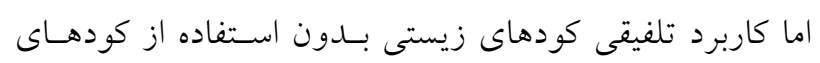
شيميايى تنها موجب افزايش معنى دار صفات رويشى كينـوا از

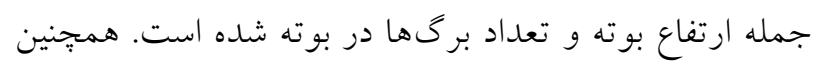

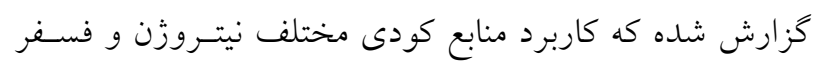

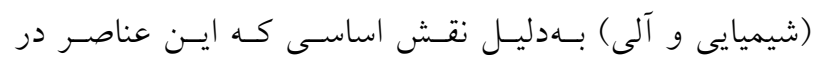

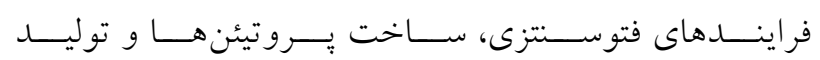

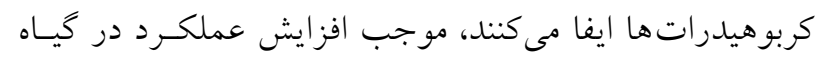

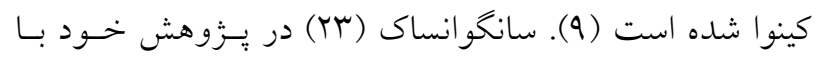

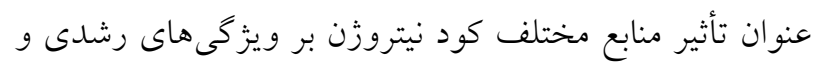

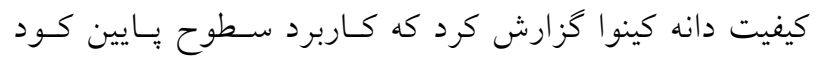

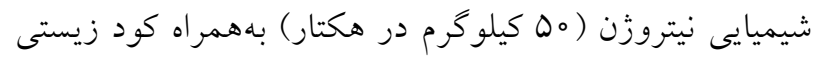
نيتروبين بيشترين تأثير را بر افـزايش معنسى دار عملكـرد دانسه

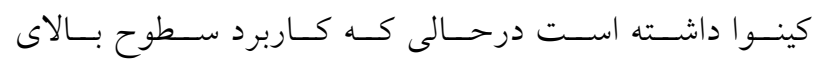

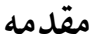

كينـوا بـا نـام علمسى Chenopodium quinoa Willd، كيـاهى يكساله، بهن برك، با ارتفاع يكى تا دو متر است كه از آمريكـاى

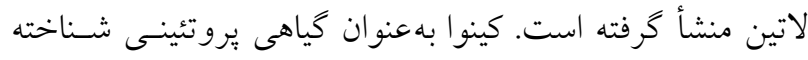

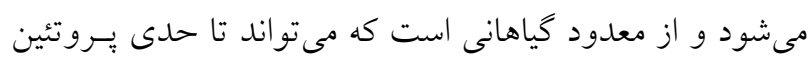

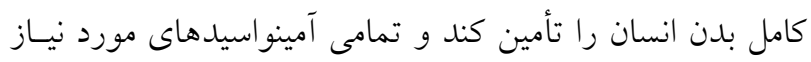

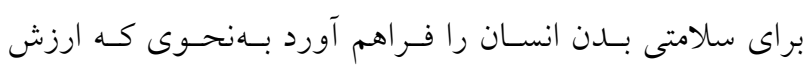

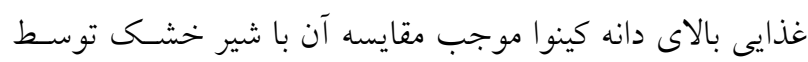

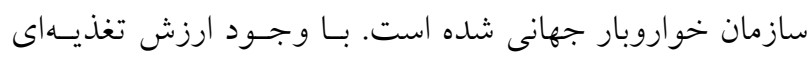

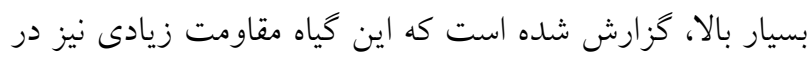

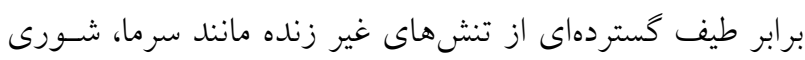
و خشكى دارد و درنتيجه جايخزينى مطلوب براى كياهانى مانند برنج است (T9) (ب9). مديريت مصرف انواع كودهاى شيميايى و آلى و بقاياى آنها

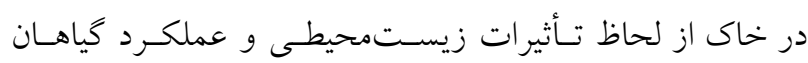
بهويزه در مناطق خشك و نيمهنشك نظير ايران داراى اهميـت

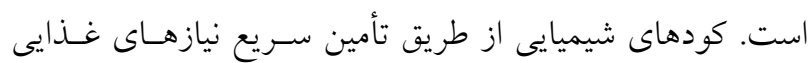

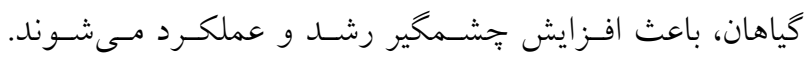

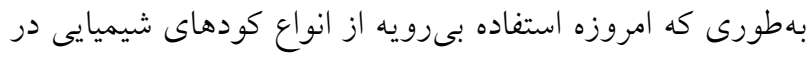

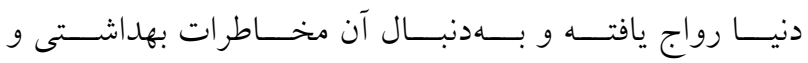

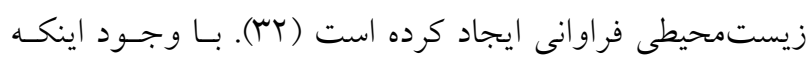

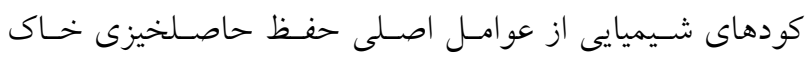

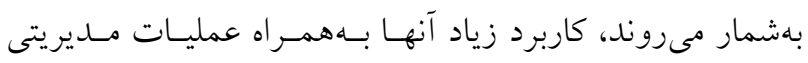

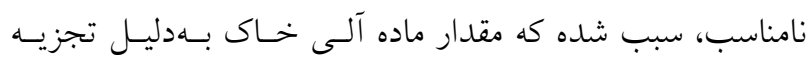

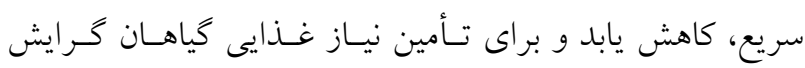
بهسمت مصرف كودهاى غيرشسيميايى صسورت يـذيرد و توليــا

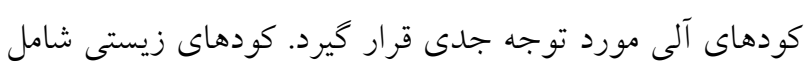

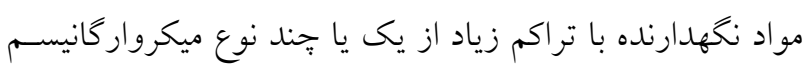

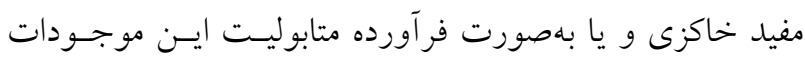

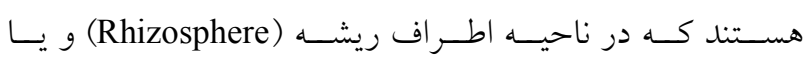
بخش هاى داخلى كياه تشكيل كلونى داده و رشد كياه ميزبـان را

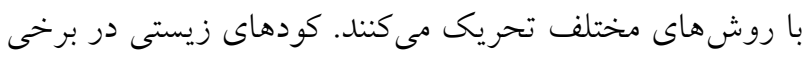


جدول ا. ويزَىىهاى فيزيكى و شيميايى خاك مزرعه

\begin{tabular}{|c|c|c|c|c|c|c|c|c|}
\hline $\mathrm{EC}_{\mathrm{e}}$ & \multirow{2}{*}{$\mathrm{pH}_{\mathrm{e}}$} & روى & بتاسيم & فسفر & ماده آلى & نيتروزن & \multirow{2}{*}{ بافت } & عمق نمونهبردارى \\
\hline (دسى زيمنس بر متر) & & \multicolumn{3}{|c|}{ (ميلى گرم در ليتر) } & \multicolumn{2}{|c|}{ (درصد) } & & (سانتى متر) \\
\hline$r / 91$ & $V / 4$ & $0 / 94$ & (ro & $9 / r$ &.$/ 09$ & $0 / 1 Y$ & لومى شنى & $\circ-r_{0}$ \\
\hline
\end{tabular}

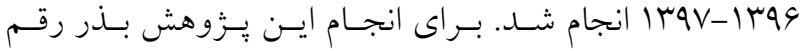
ساجاما از شركت كيان تجارت سانا اسـتان كلسـتان تهيـهـ شــــ تيمارهاى اين آزمايش شامل: كودهاى شيميايى در خهار سـطح:

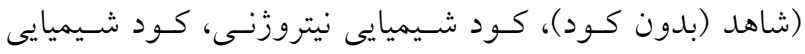
فسفردار، تلفيق كود شيميايى نيتروزنى و كود شيميايى فسفردار) و فاكتور دوم كودهاى زيستى شامل جهار تيمار: (شاهد (بـدون

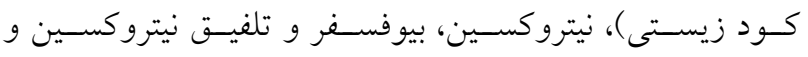
بيوفسفر) بود. براى تأمين عناصر مورد نياز كياه بر اساس نتسيايج

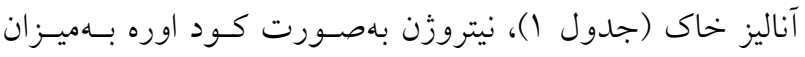

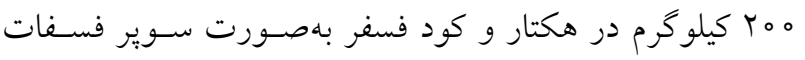

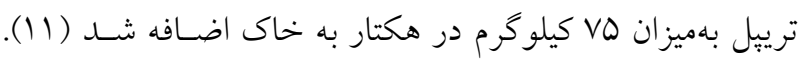

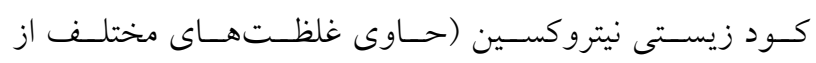

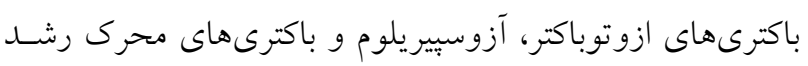

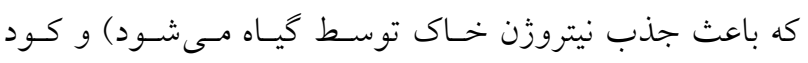
زيستى بيوفسفر (باكترىهاى موجود در آن حاوى بـاكترىهـايى بـوني

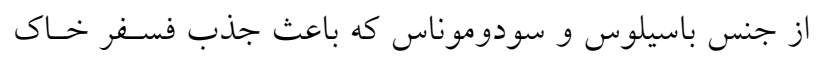

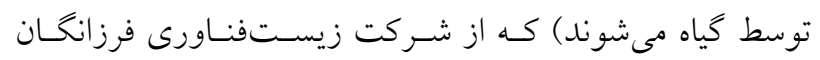
خريدارى شده بودند، بر اساس توصيه شركت سازنده (مصـرف

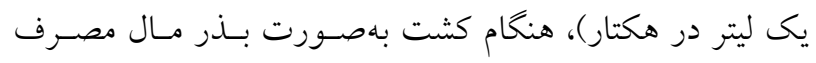

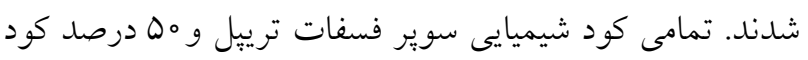

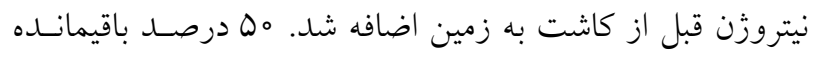

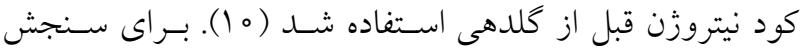

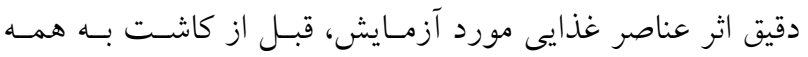

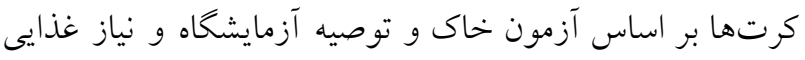

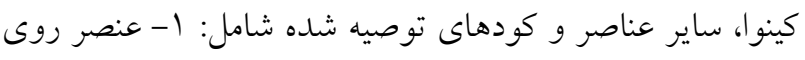

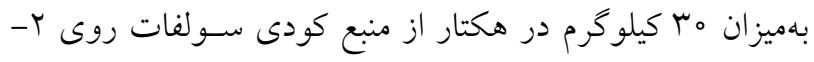

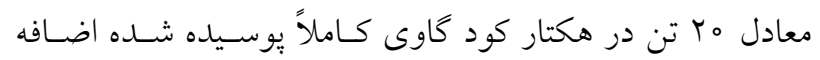

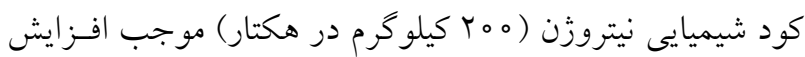
حداكثرى صفات رويشى از جمله ارتفاع بوته شده است. نتـايج

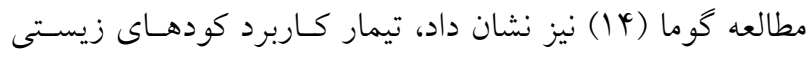

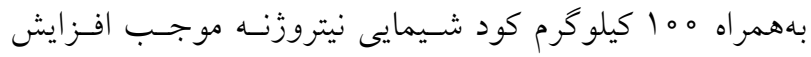

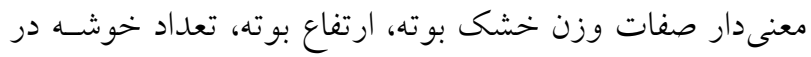
مترمربع، عملكرد دانه و عملكرد بيولوزيكى در كيـاه كينـوا شـــهـ است. كياه كينوا بهتازگى از طرف وزارت جهاد كشاورزى بـراى كشت در مناطق شور و با محدوديت تـأمين آب كـافى، توصسيه

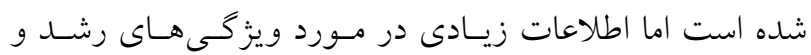

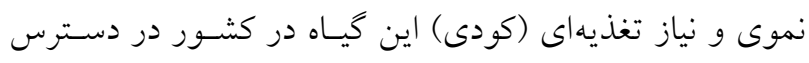

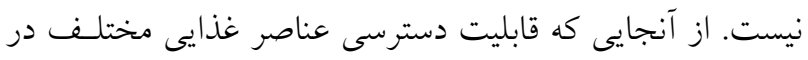

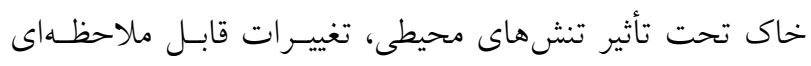

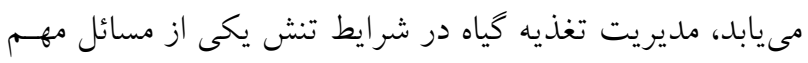

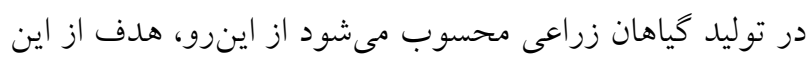

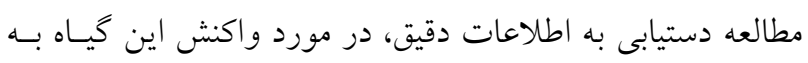

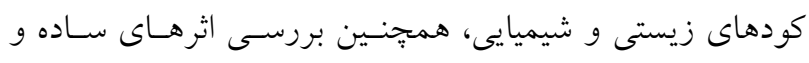

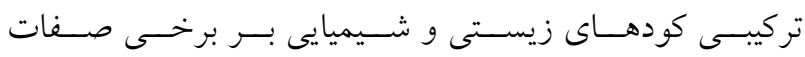

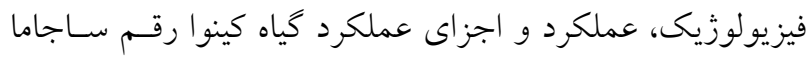
بوده است.

\section{مواد و روشها - - ماد}

بهمنظور بررسى تأثير كودهاى زيستى و شيميايى بر عملكرد

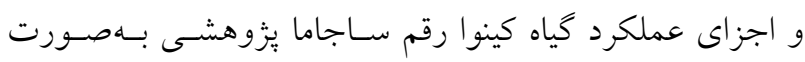

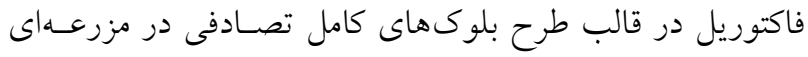

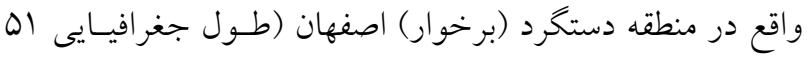

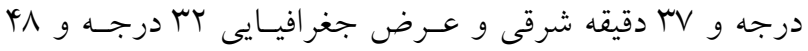

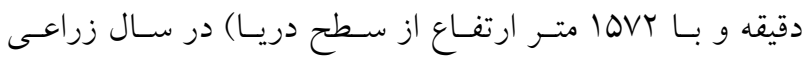


تأثير معنى دارى نداشت (جدول Y). مقايسه ميـانخين اثـر سـاده

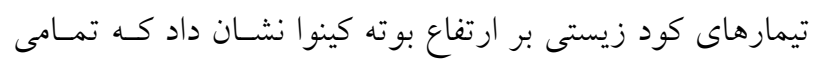

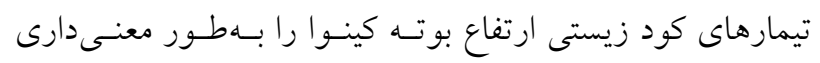

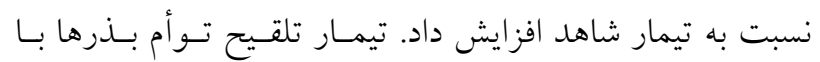

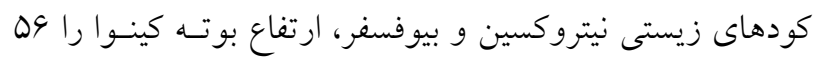

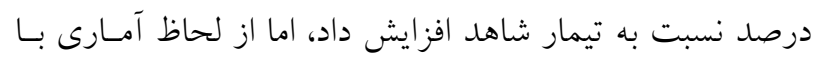

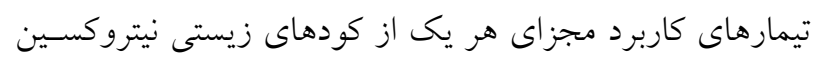

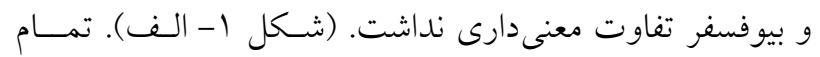

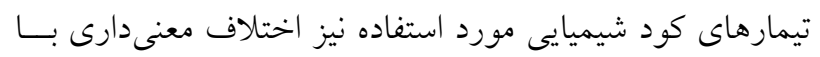

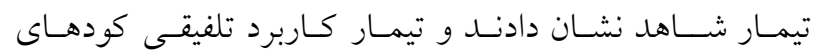

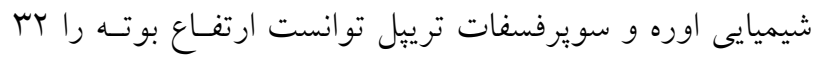

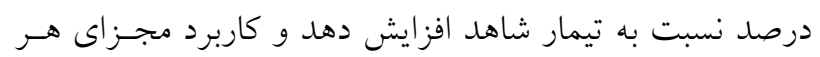

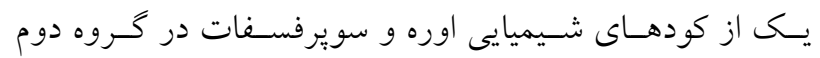

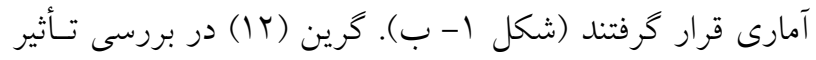

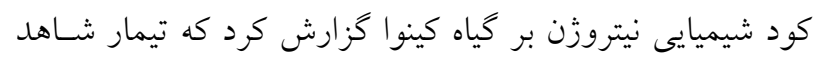

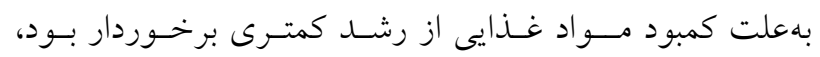

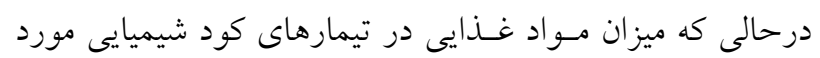

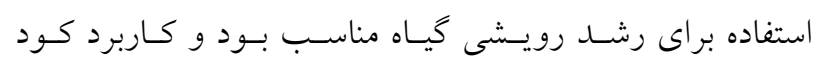

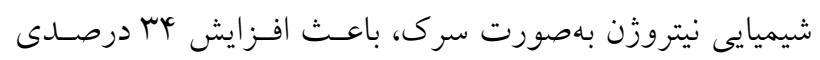

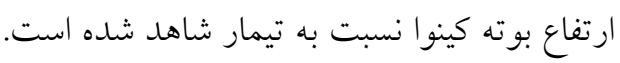

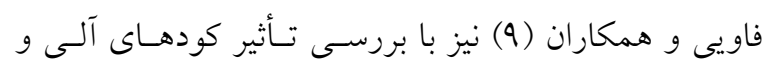

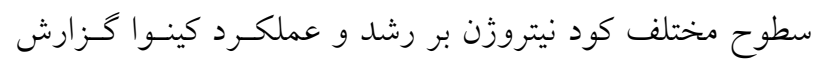

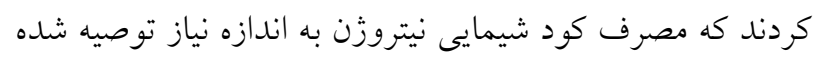

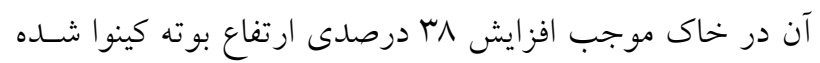

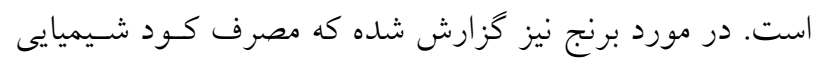

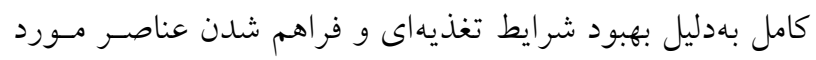

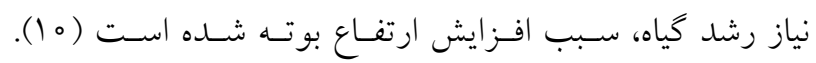

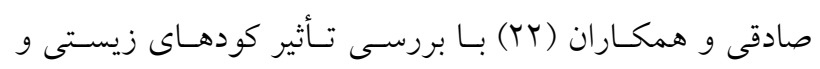
مديريت حاصلخيزى خاك بر شاخص هاى رشدى دو رقم ذرت هات

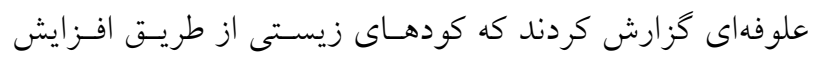

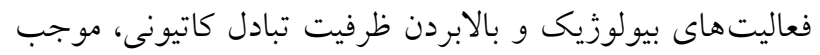
بهبود ساختمان خاك مسىشـوند. ايسن عامـل (بهبـود سـاختمان
شد. هر واحد آزمايشى در اين مطالعه شامل شش رديف كاشت

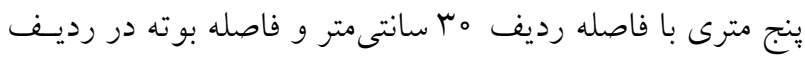

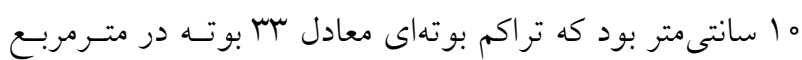

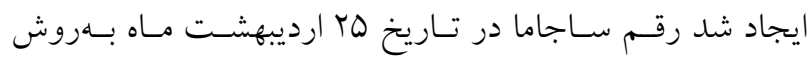

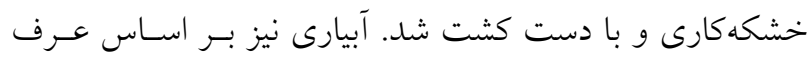
منطقه صورت گرفت. شاخص سطح برى بيان كننده سطح برى

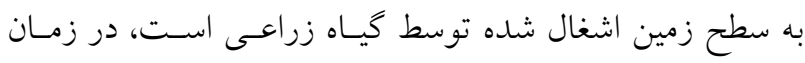

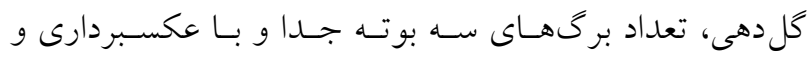

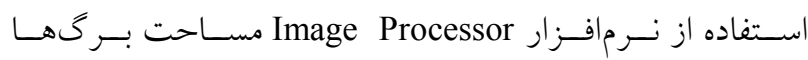

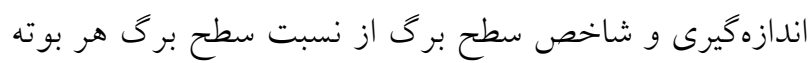

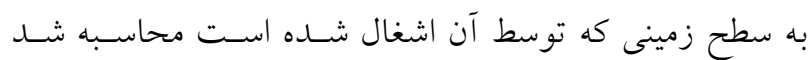

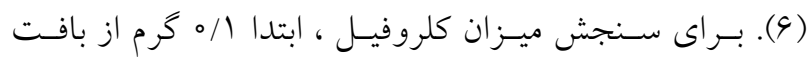

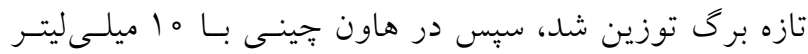

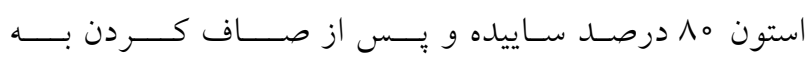

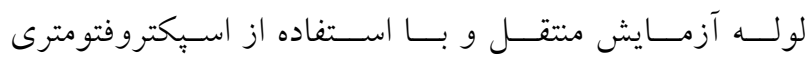
مــل VIS-UV

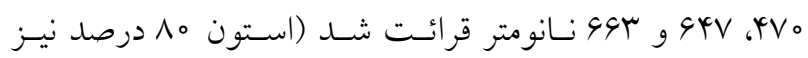

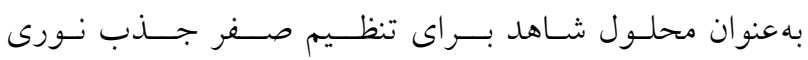

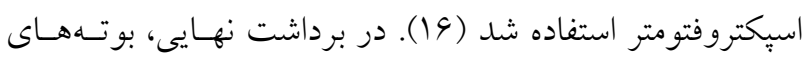
برداشت شده از يك مترمربع وزن و عملكرد بيولوزيـك تعيـين

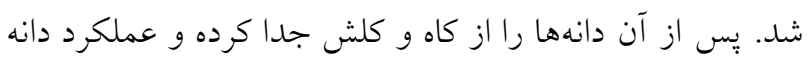

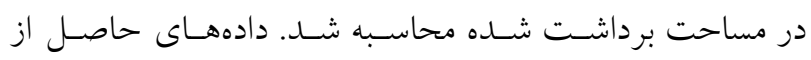

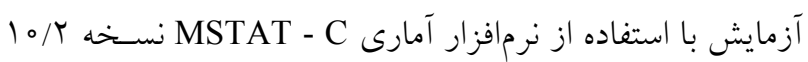
مورد تجزيه واريانس قرار كرفت و ميانخينها بسهوسـيله آزمهون

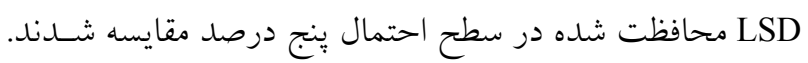
براى رسم شكلها از برنامه Excel استفاده شد.

\section{نتايج و بحث \\ ارتفاع بوته}

نتايج تجزيه واريانس نشان داد كه ارتفــاع كيـاه كينـوا در سـطح

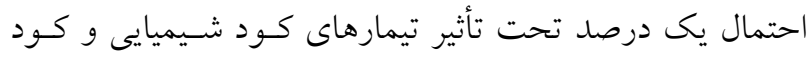

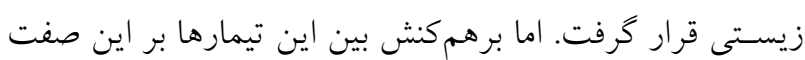




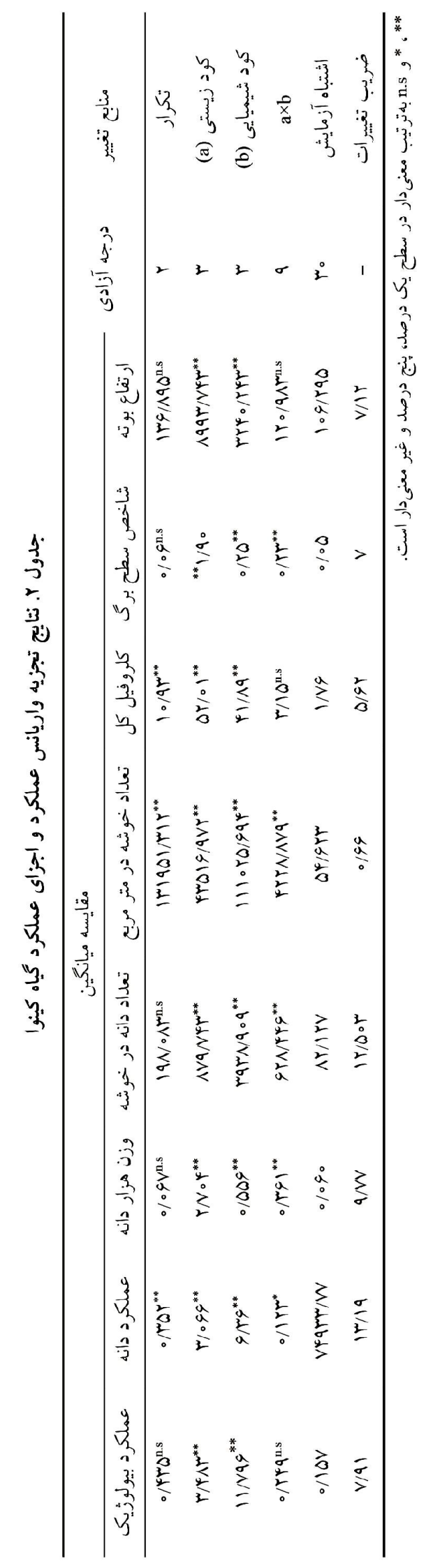



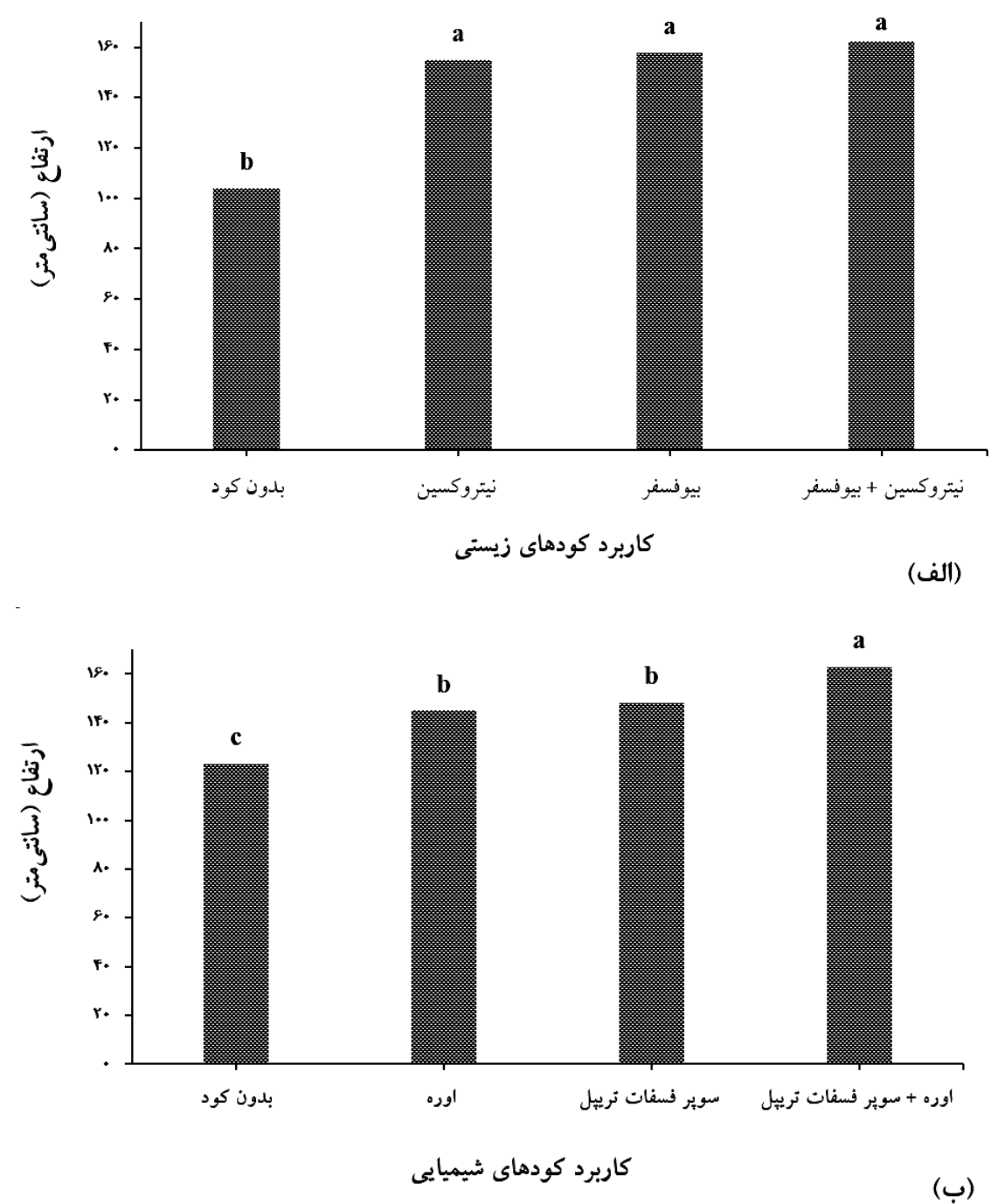

شكل 1. تأثير: الف) كودهاى زيستى و ب) كودهاى شيميايى بر ارتفاع بوته كينوا رقم ساجاما

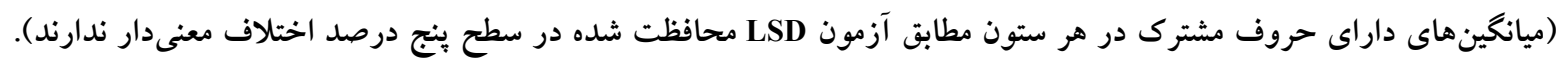

سطح برى كينوا در سطح احتمـال يـى درصـد معنس دار شـد.

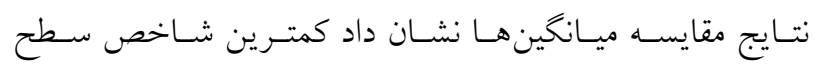

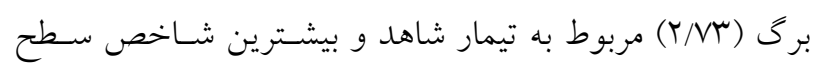

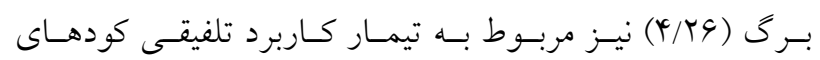

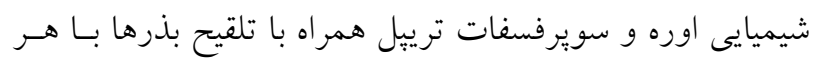

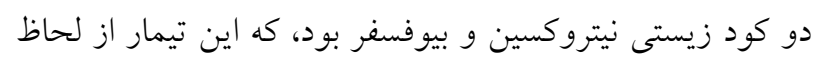

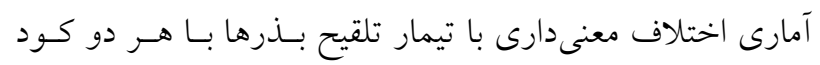

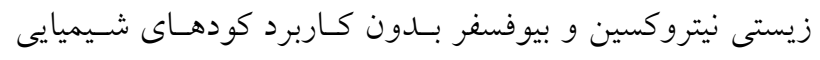

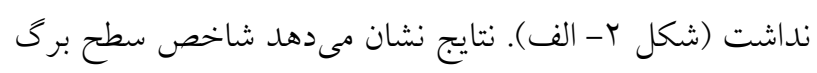

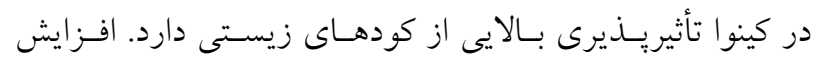

خاى) ظرفيـت نخهـدارى رطوبـت در خـاك را افـز ايش داده و

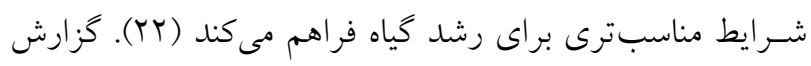

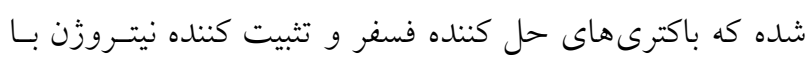

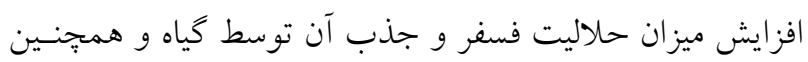

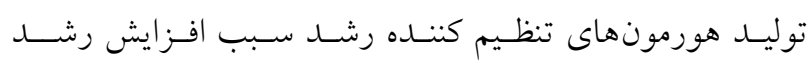

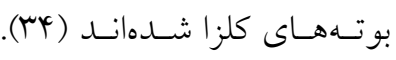

$$
\text { شاخص سطح برى }
$$

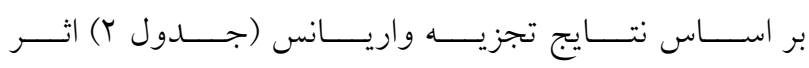

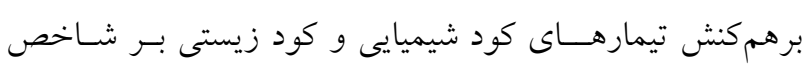



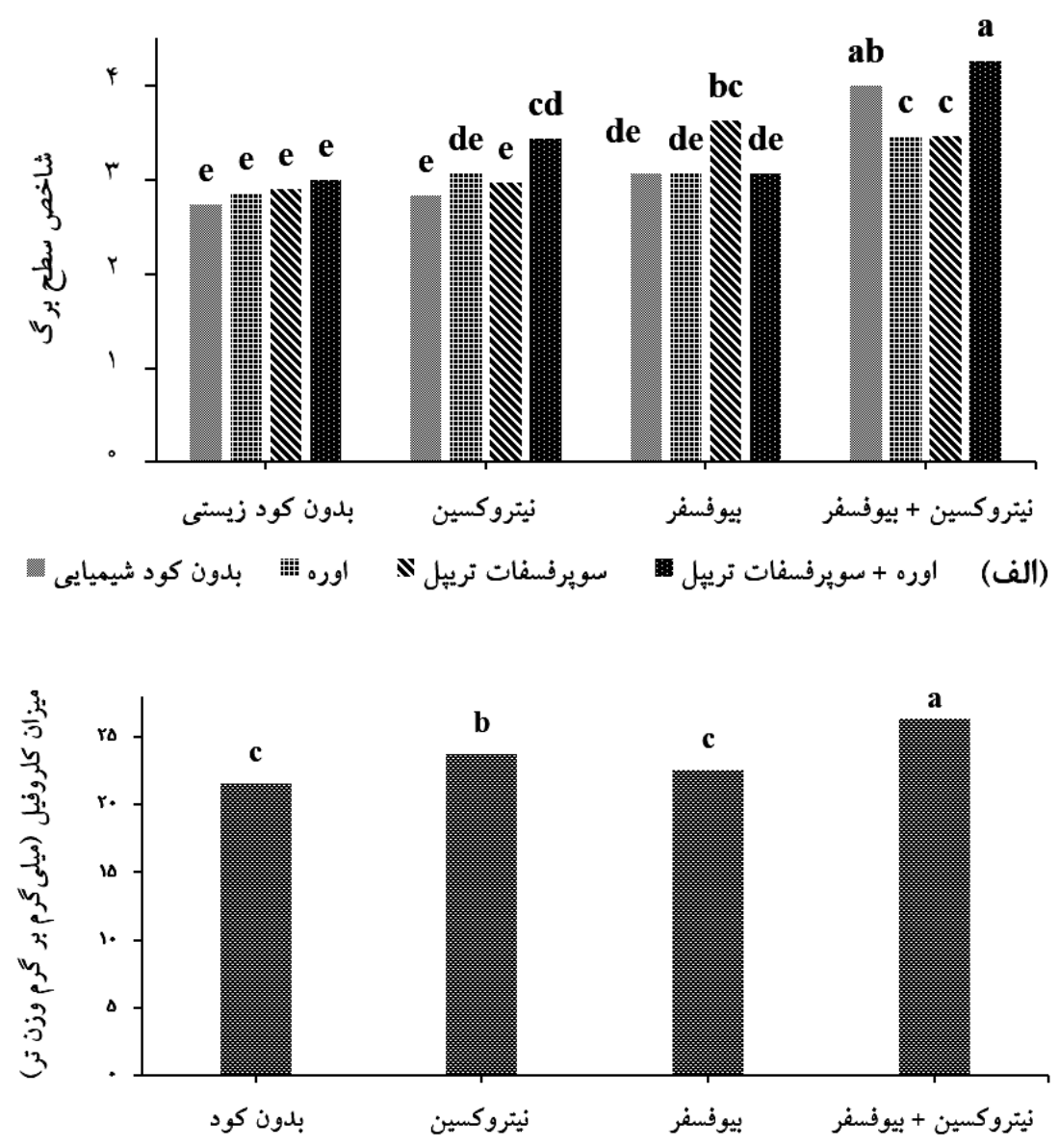

كاربرد كودهاى زيستى

$(1-\varphi)$

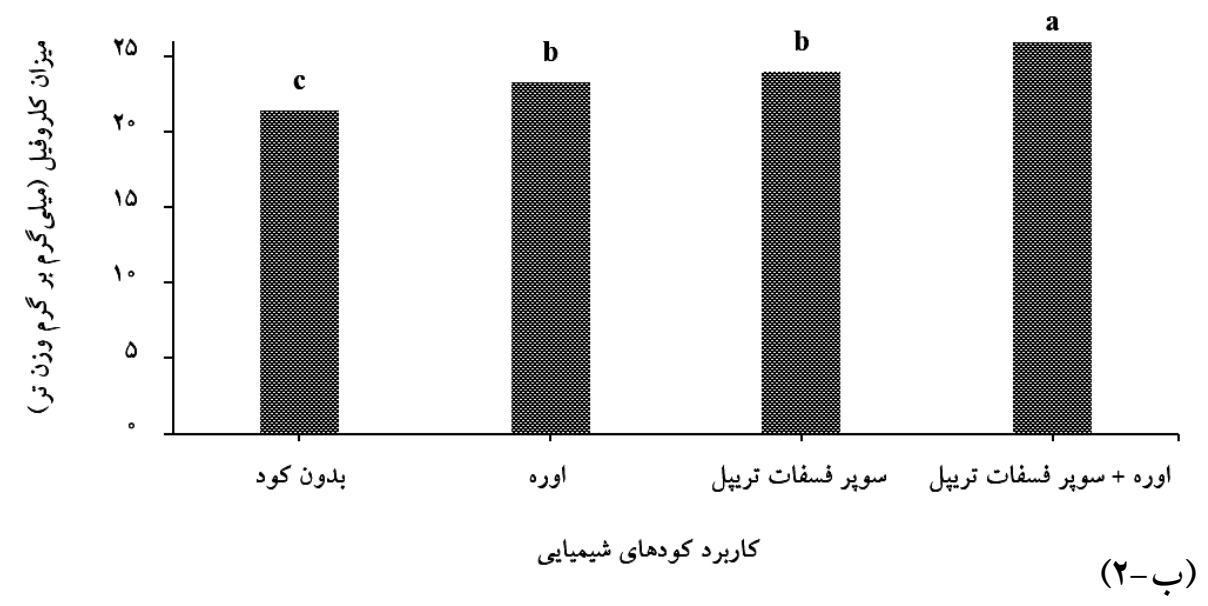

شكل r. الف) اثر برهم كنش تيمارهاى كود شيميايى و كود زيستى بر شاخص سطح برى كينوا رقم ساجاما، ب- () تأثير كودهاى

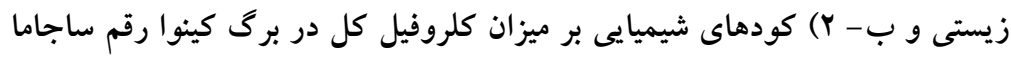

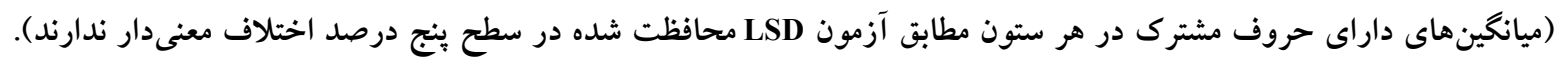


موجب اختلاف معنى دار در ميزان كلروفيل كينوا شـدند اما اثـر برهم كنش اين تيمارها بر ايسن صـفت معنىدار نبــود (جـــدول

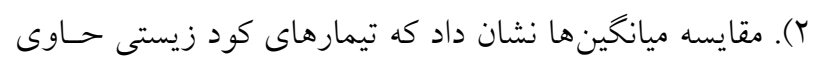
نيتروكسين بيشترين تأثير را بر افزايش ميزان كلروفيل كياه كينـوا داشتند بهنحوى كه بالاترين ميزان كلروفيل در تيمار تلقيح تـوأم بذرها با هر دو كود زيستى نيتروكسين و بيوفسـفر و يسس از آن

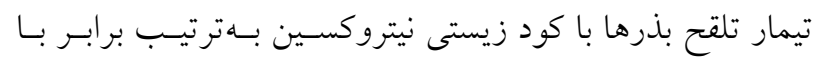

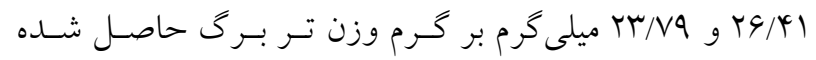
است (شكل r- ب- (1). درنتيجه بهنظر مسىرسـد اتـر كودهـاى بيولوزيك بر افزايش كلروفيل بـرگ، بـهــور اساسـى از طريستق

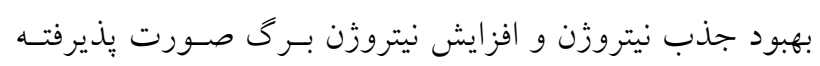
باشد، كه از يكسو باعث فراهمى بيشسازهاى كلروفيل شده و

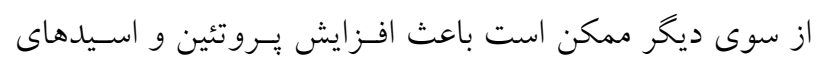

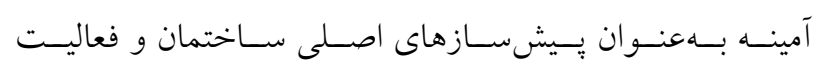

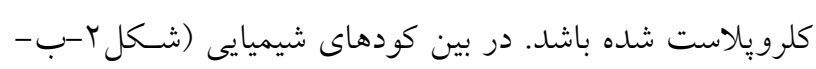

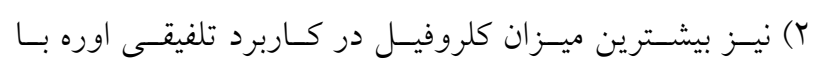

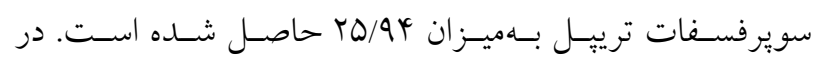
يزوهشى تأثير كودهايى شيميايى بر افزايش ميزان كلروفيل ارقام كينوا مثبت كزارش شده است (91). قيميره و همكاران (سا) نيز در يزّوهش روى ارقام مختلف ذرت، اتخر كـود شـيميايى را بـر افزايش غلظت كلروفيـل ذرت در سـطح يـك درصــ معنسى دار

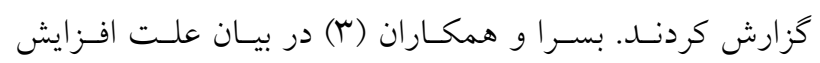

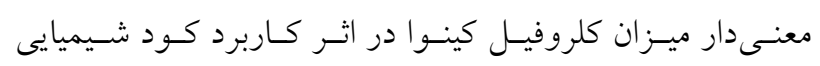
نيتروزن نسبت به تيمار شاهد، گزارش كردند كه نيتـروزن بـرى

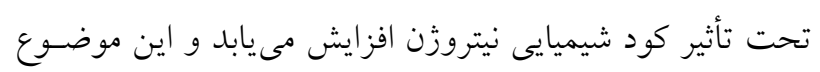
افزايش محتواى كلروفيل برى را بههمراه دارد.

\section{تعداد خوشه در مترمربع}

تعداد خوشه در مترمربع در كياه كينوا تحت تأثير كود شسيميايى، كود زيستى و اثر برهمكسنش كـود شـيميايى و كـود زيسـتى در سطح احتمال يك درصد معنى دار بود (جدول r). همان طور كه در شكل ب- الـف مشـاهده مسىشـود، در تمـامى سـطوح كـود
سطح برى تعيين كننده ظرفيت فتوسنتزى كياه است و تغييـر در

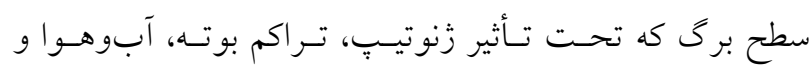

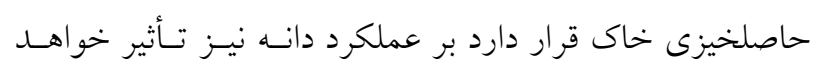

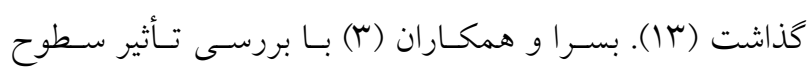
مختلف كود شيميايى نيتروزن بـر زنوتيـِّهـاى مختلـف كينـوا كزارش كردند كه كاربرد كود شيميايى نيتروزن به انـدازه ميـزان

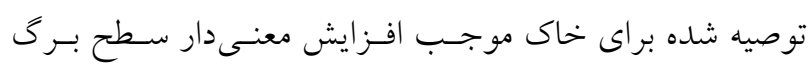

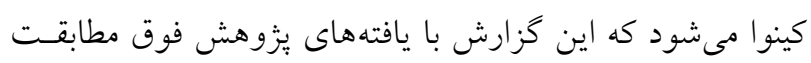

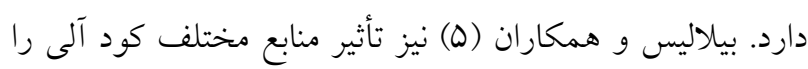

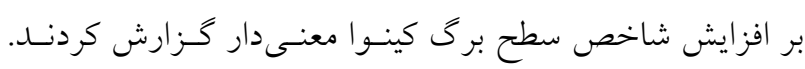
افزايش شاخص سطح برى در تيمارهاى كاربرد تلفيقى كودهاى

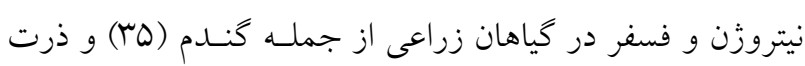

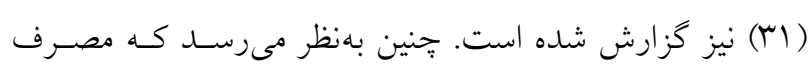

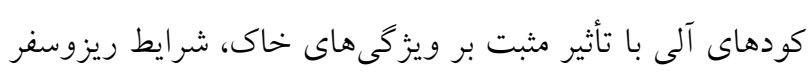

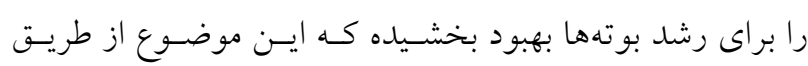
افزايش و تحريك رشد كياه، افـزايش سـطح بـرى را بـهدنبـال داشته است. از طرفى منابع كودى فسفر موجود در يزوهش نيـز تأثير زيادى بر شاخص سطح برى كينوا داشته است بهنحوى كه تيمار كاربرد كود شيميايى سويرفسفات تريبـل بـههمـراه تلقسيح بذرها با كود زيستى بيوفسـفر بـراى ايسن صـفت در خـروه دوم

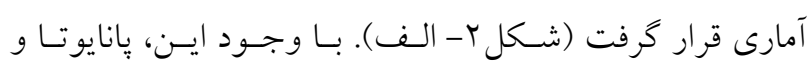
همكاران (19) اثر منابع مختلف كودى را بر شاخص سطح برى كينوا معنى دار گزارش نكردند. گزارش شــده كـه اضـافه كـردن فسفر موجب بالارفتن تعداد و طول ساقههـا در گياهـان زراعى

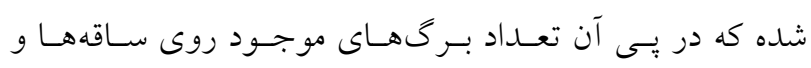

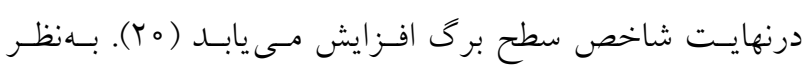
مىرسد فسفر با مشاركت در فرايندهاى رشدى و تقسيم سلولى

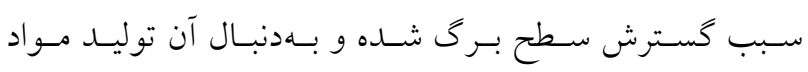
فتوسنتزى و افزايش عملكرد را بههمراه داشته است.

ميزان كلروفيل كل تيمارهاى كود شيميايى و كود زيسـتى بـا احتمـال يـك درصــ 


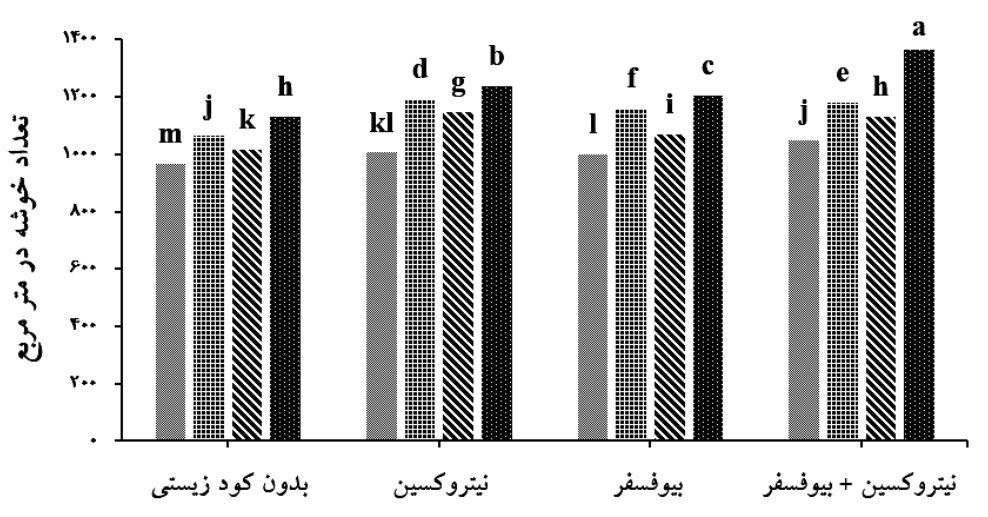

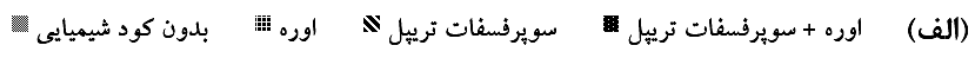

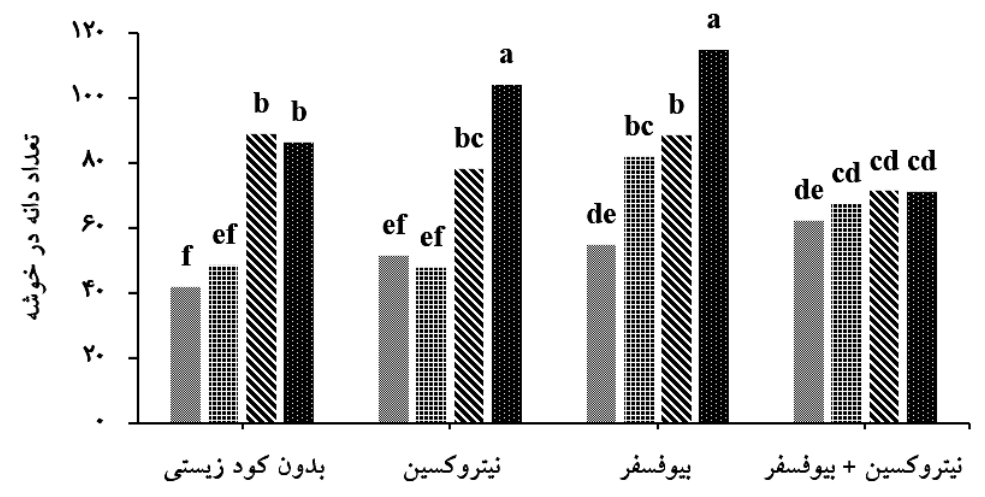

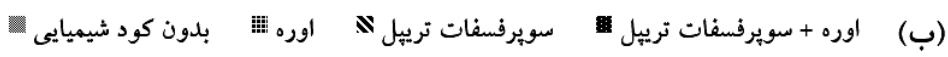

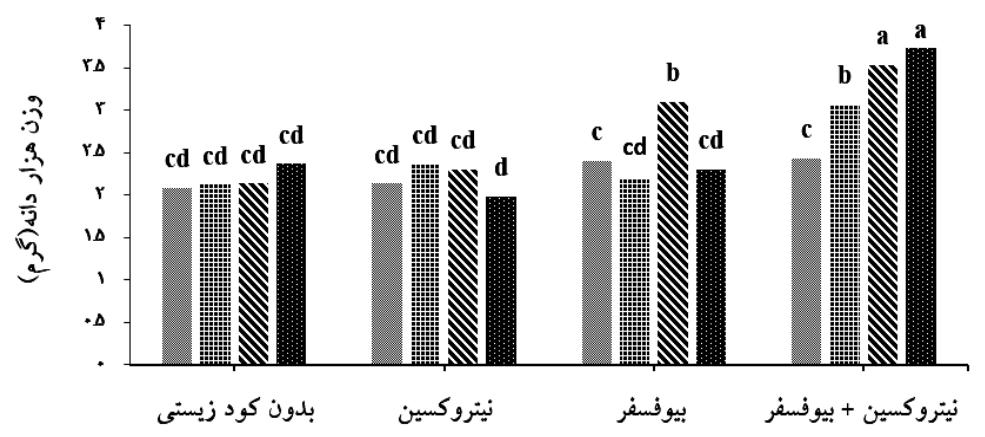

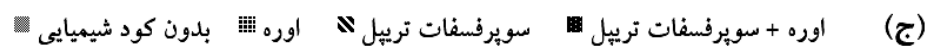

شكل r. اثر برهم كنش تيمارهاى كود شيميايى و كود زيستى بر: الف) تعداد خوشه در متر مربع، ب) تعداد دانه در خوشه و ج) وزن هزار دانه كينوا رقم ساجاما

(ميانخينهاى داراى حروف مشترك در هر ستون مطابق آزمون LSD محافظت شده در سطح پينج درصد اختلاف معنىدار ندارند).

زيستى، تيمارهايى كه تلفيق كودهاى شيميايى نيتـروزن و فسـفر برخوردار بودند و كاربرد كود شيميايى نيتروزن در كليه سـوح را دريافت كرده بودند از تعداد خوشـه (در متـرمربـع) بيشـتى كود زيستى در خـروه دوم آمـارى قـرار كرفـت. بـهنحـوى كـه 
افـزايش حفظظ سـلامتى ريشه در طول دوره رشد در رقابت بـا

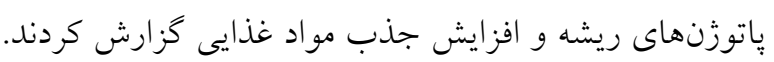

\section{تعداد دانه در خوشه}

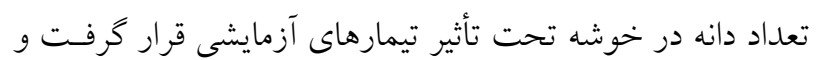
هر يك از اثرات ساده كاربرد كود شيميايى و تلقيح كود زيستى و

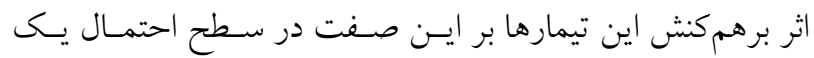

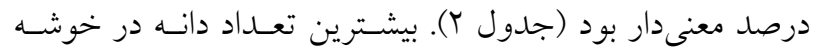
(1) العدد دانه) در تيمار تلقيح بـــرها بـا كـود زيسـتى بيوفسـفر بههمراه كـاربرد تلفيقسى كودهـاى شـيميايى اوره و سويرفسـفات

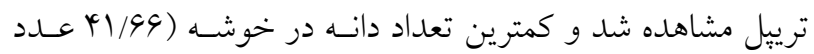
دانه) مربوط به تيمار شاهد بود (شكل ؟َ-ب). در تيمارهـايى كـه

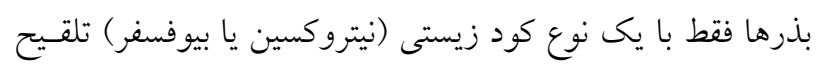

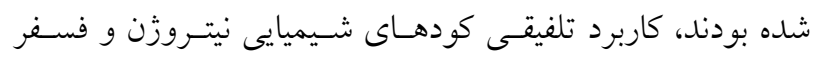

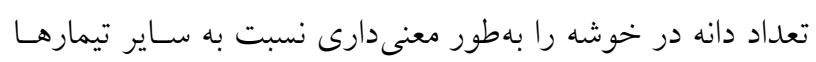

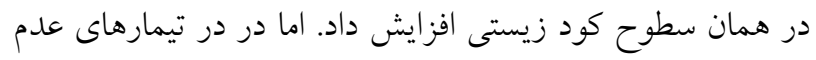

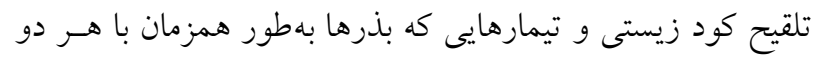

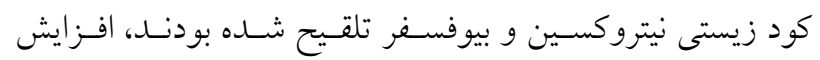

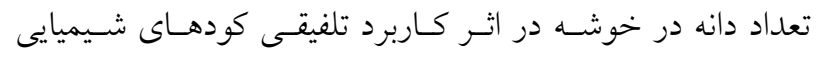
اختلاف معنى دارى با تيمـار كـاربرد كـود شـيميايى سويرفسـفات

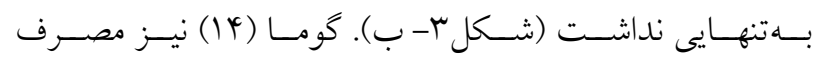

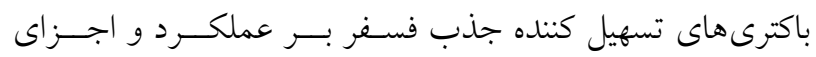

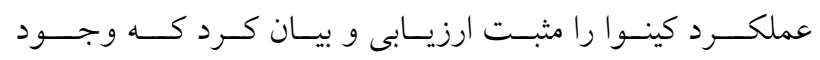
بـاكترىهـاى تسهيل كننده جذب فسـفر بـا توجـهـ بـه نقشى كـهـ

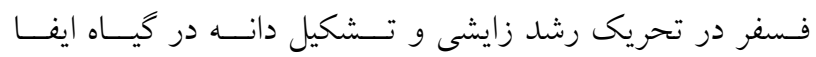

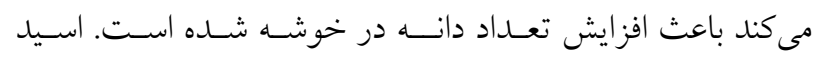
ايندول استيك دركنار سيتوكنين كه توسط كودهاى زيستى توليـــ

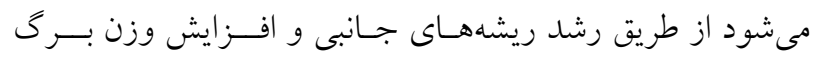

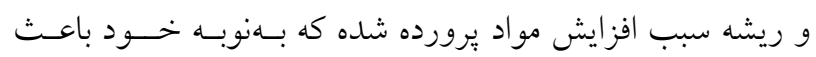

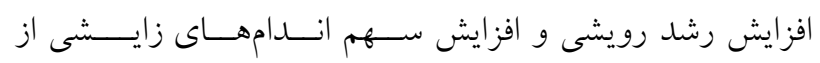

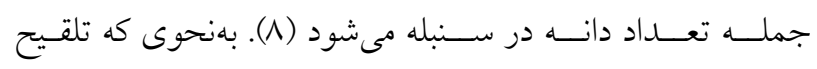
كـود زيسـستى بـهمهـراه كـاربرد كـود شـيميايى فسـفر در كيـاه
بيشترين تعداد خوشه با ميانخين هوبا عدد خوشه در مترمربـع، مربوط به تيمار كاربرد تلفيقى كودهاى شيميايى و تلقـيح بـــرها

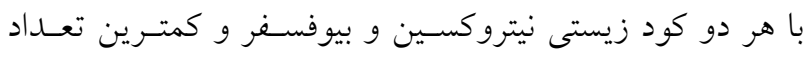
خوشه (991 عدد خوشه در مترمربع) مربوط به تيمار شـاهد يـا يـا

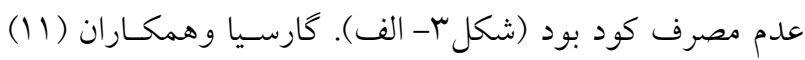

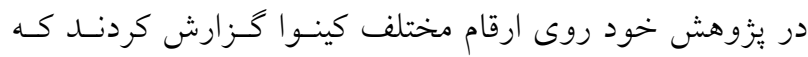

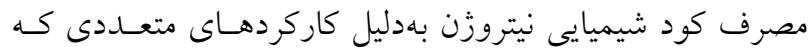

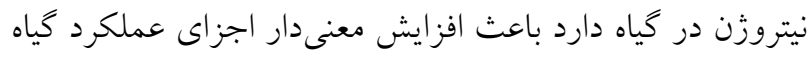
كينوا از جمله تعداد خوشه در مترمربع مىشودد. مــصرف كـود

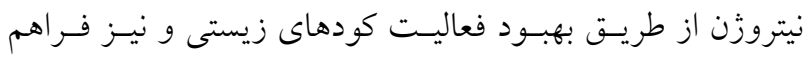
شدن جذب بيـشتر مـو اد غذايى سبب افـزايش ميـزان فتوسـتنز مىشود كـهـ ايسن مسئله درنهايت به افــز ايش تعـــاد ســنبله و

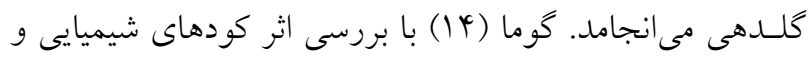
زيستى نيتروزن و فسفر كزارش كرد كه مصـرف همزمـان كـود شيميايى و كودهاى زيستى بهدليل تأمين عناصر مورد نيـاز گيـاه

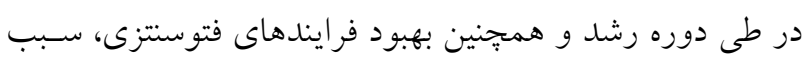

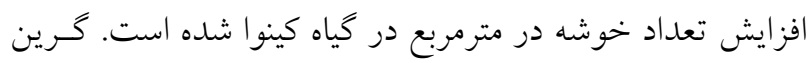

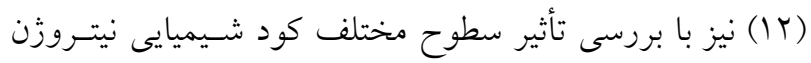

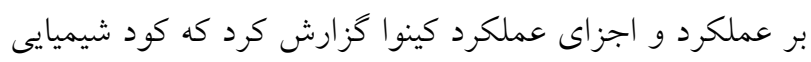

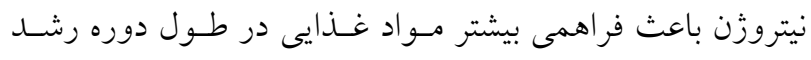

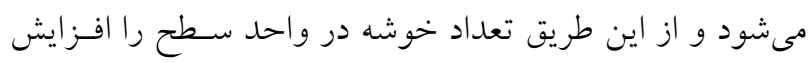

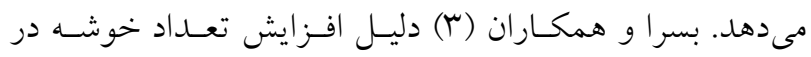

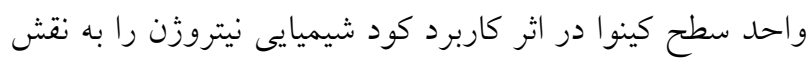

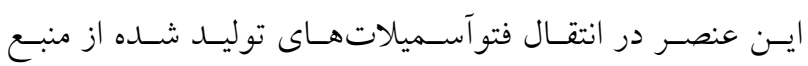

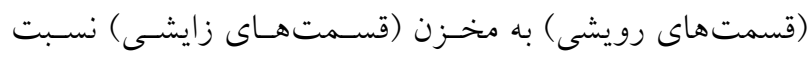

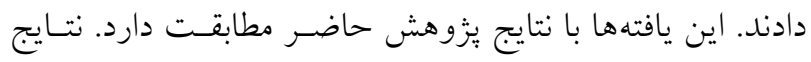

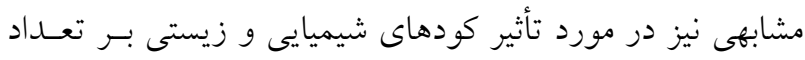

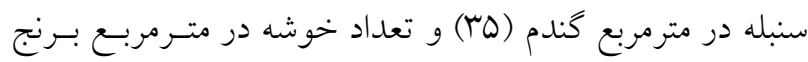

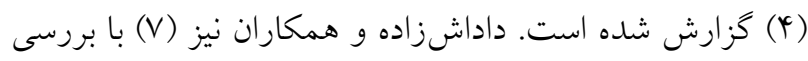

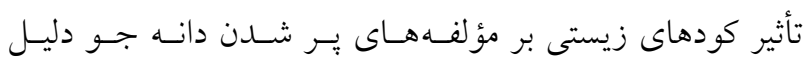

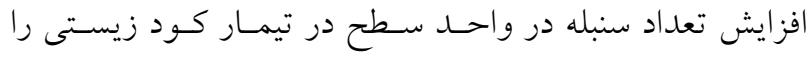

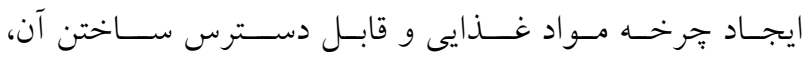


زيستى داخل خاك مهيا كـرده و از طريق جذب مو اد غذايى توسط

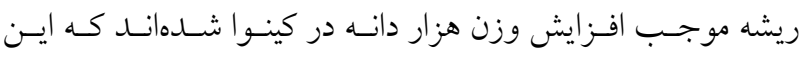
موضوع با يافتهاى بزوهش حاضر مطابقت دارد افـزايش معنسى دار

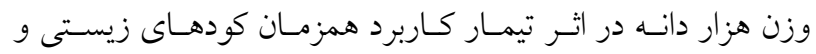

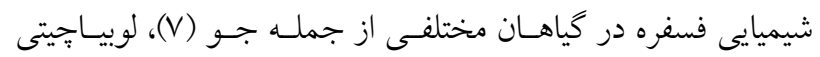
(TN)

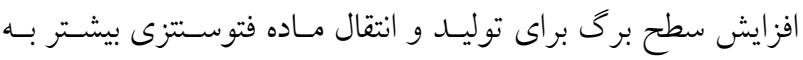

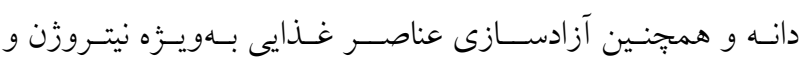

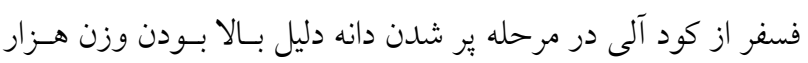

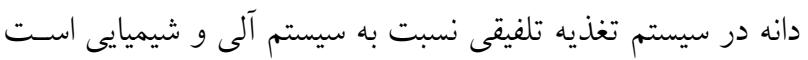

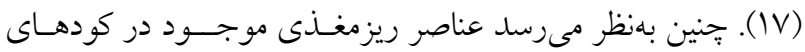

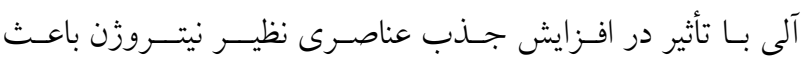

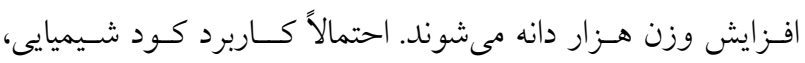

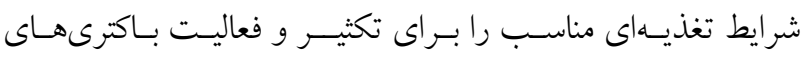

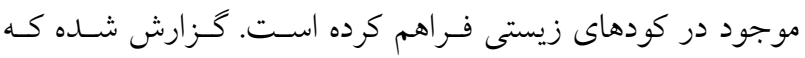
تيمارهاى كود زيسستى مناسـب در مقايسه با تيمار شـاهد شـيميايى دوديى

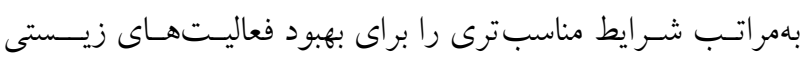

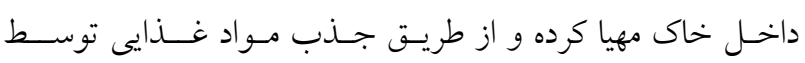

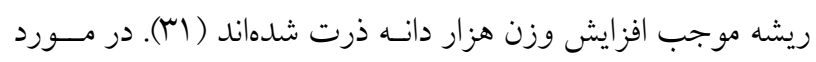

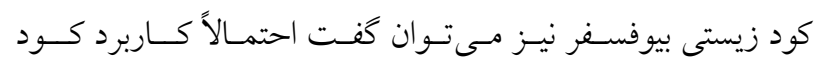

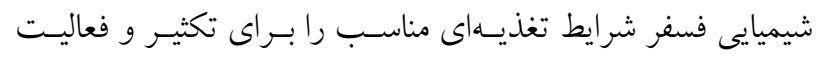

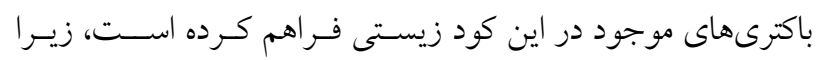

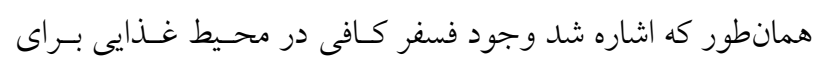

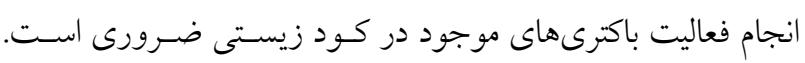

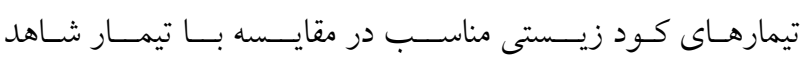

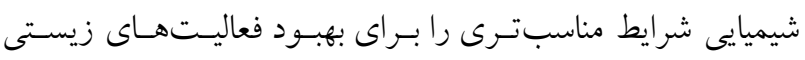

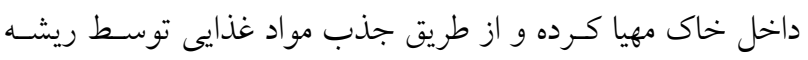
موجـب افززايش وزن هزار دانه شدهاند.

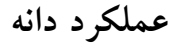

عملكرد دانه كينوا تحت تأثير تيمار كودهاى شيميايى و تيمـار

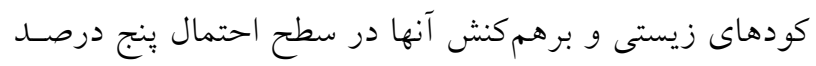

آفتـابكردان سـبب افزايش IV درصسـى تعـداد دانسه در طبـق

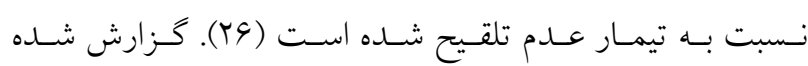
بهلطور كلى كودهاى زيستى در كنار كود شيميايى به مقــار مـورد

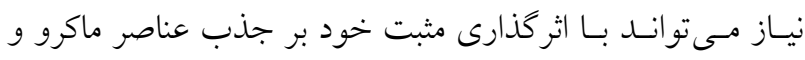

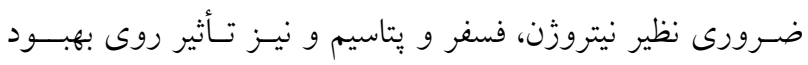

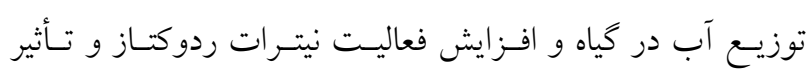

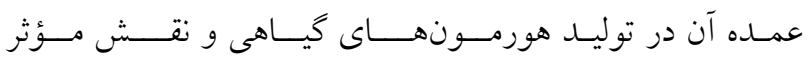

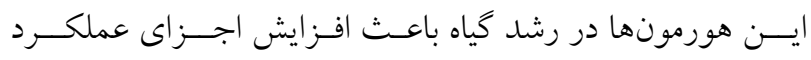

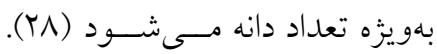

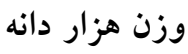
بر اساس نتايج جدول تجزيه واريانس اثر كاربرد كودهاى شـيميايى،

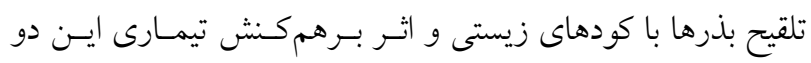

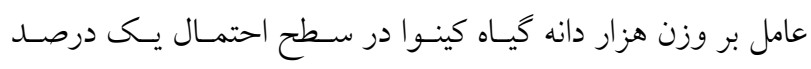

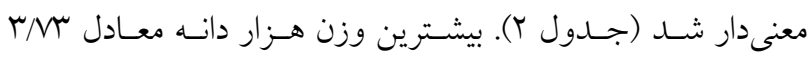

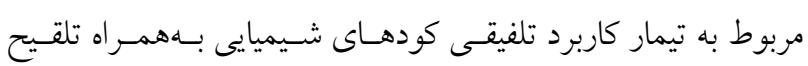

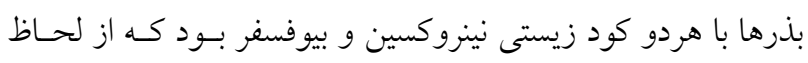

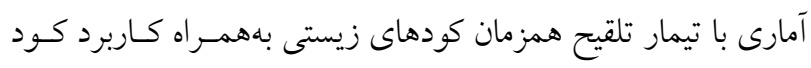

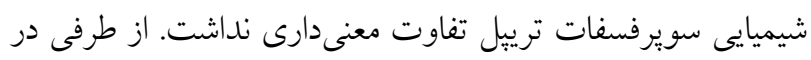

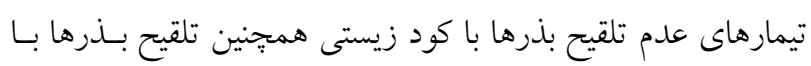

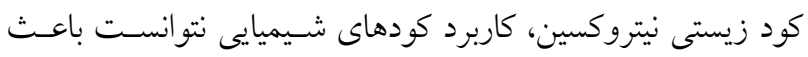

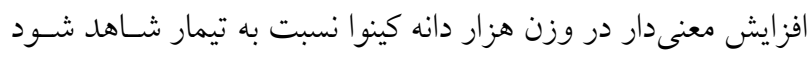

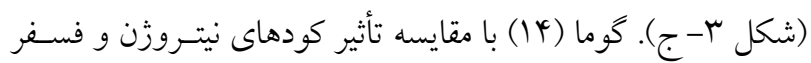

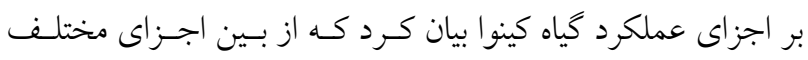

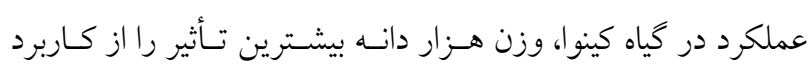

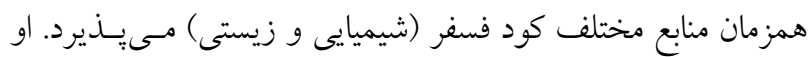

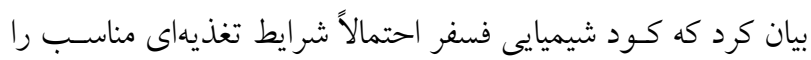
براى تكثير و فعاليت باكترىهاى موجود در كودهاى زيستى فـراهم

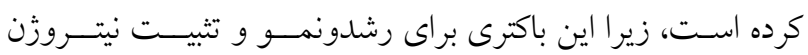

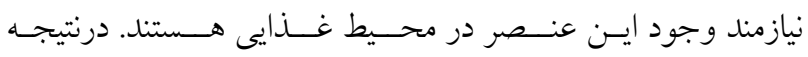

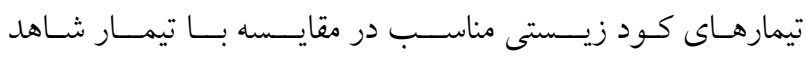

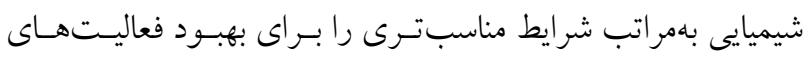


باكترىهاى حل كننده فسفات، در حضور فسـفر شـيميايى بـالا،

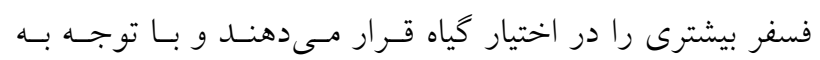

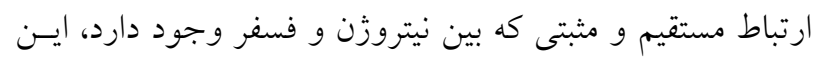

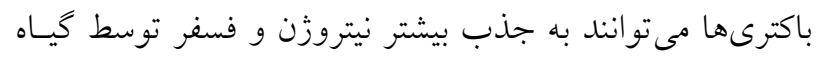

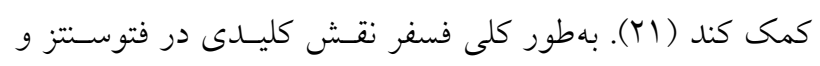

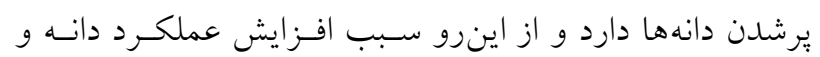

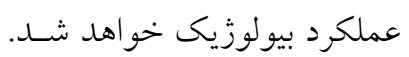

\section{عملكرد بيولوزيك}

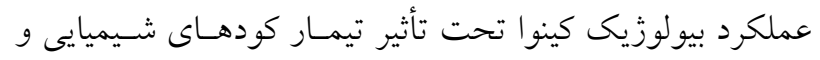

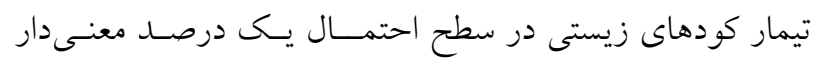

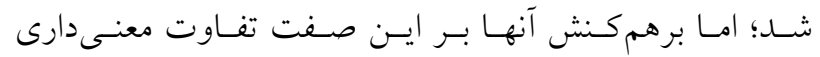

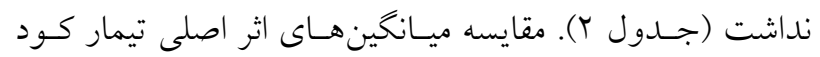

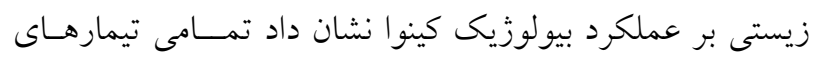

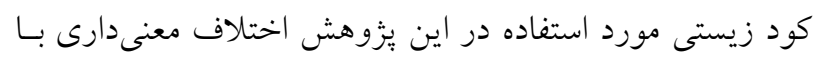

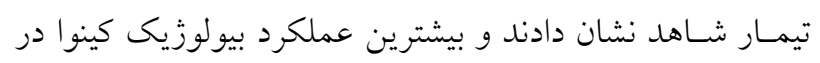

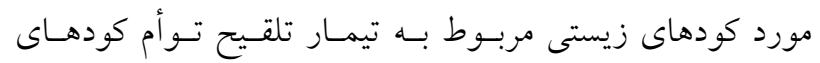
زيستى نيتروكسين و بيوفسفر بود كه از لحـاظ آمـارى بـا تيمـار

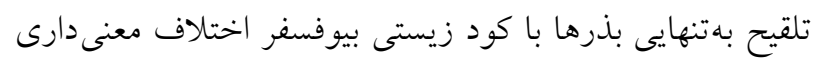

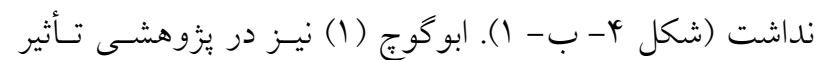

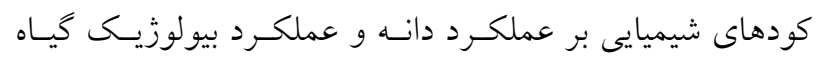

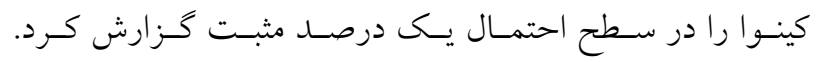

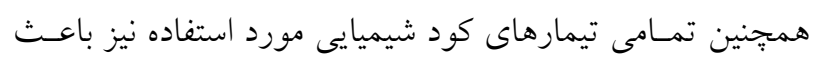

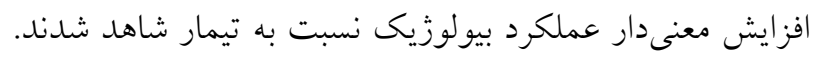

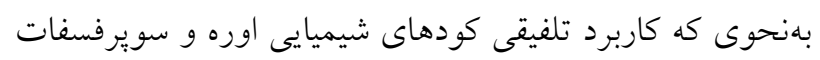

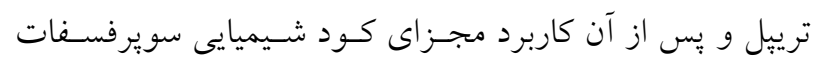

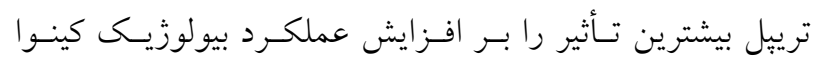

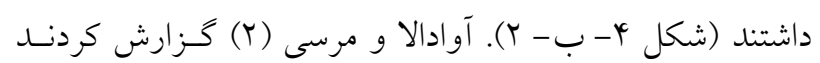

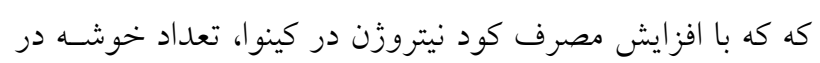

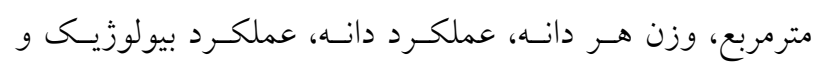

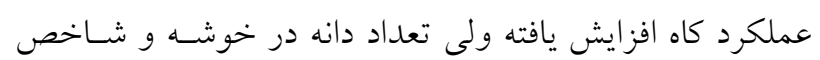
برداشت با كاهش همراه بوده است.

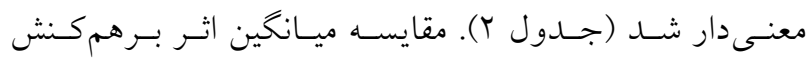

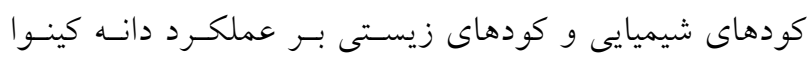
نشان داد، در تمام سطوح كود زيستى كاربرد تلفيقى كودهـاى ونسي شيميايى اوره و سويرفسفات تريبل توانست عملكرد دانه كينوا را بهطور معنى دارى نسبت به ساير تيمارها در همان سطح كود

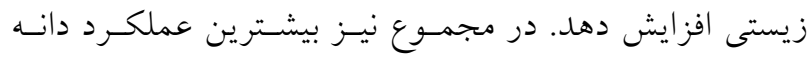

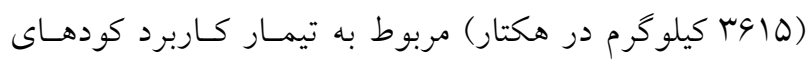

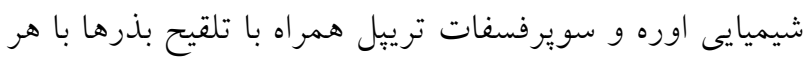

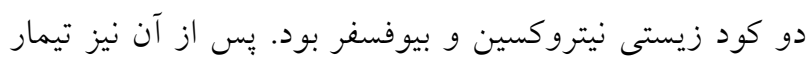

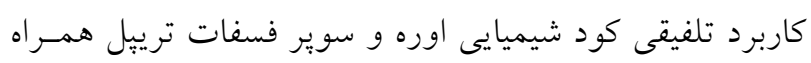

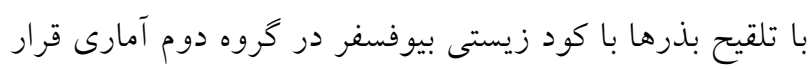

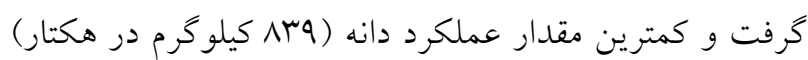

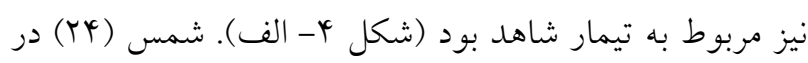
يزوهشى تأثير كودهاى شيميايى بر افزايش عملكرد دانه ارقـام

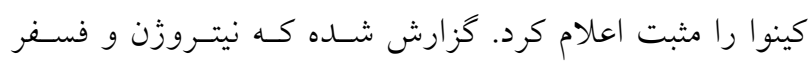

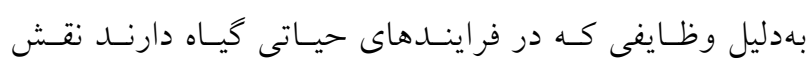

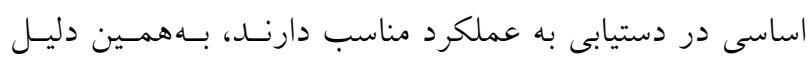

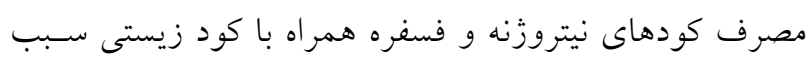

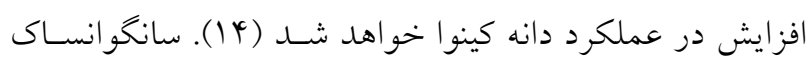

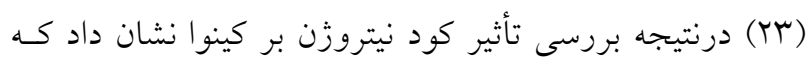

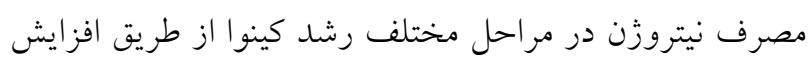

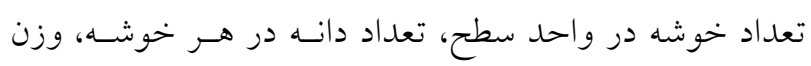

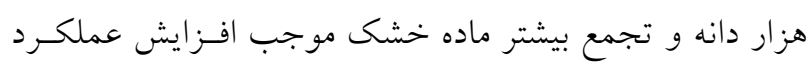

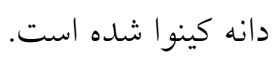

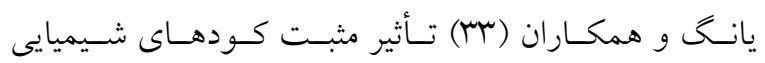
نيتروزنه و فسفره را بر بهبود فتوسنتز، از دلايل افزايش عملكسرد

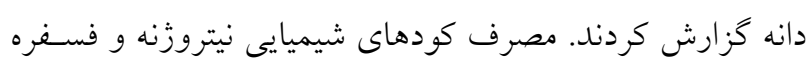

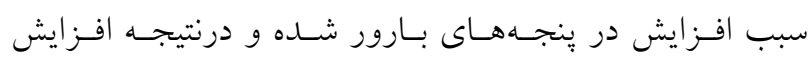

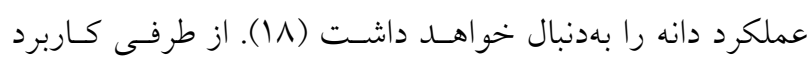

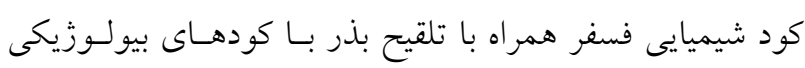

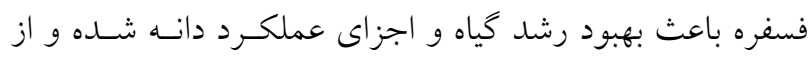

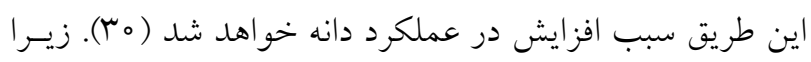




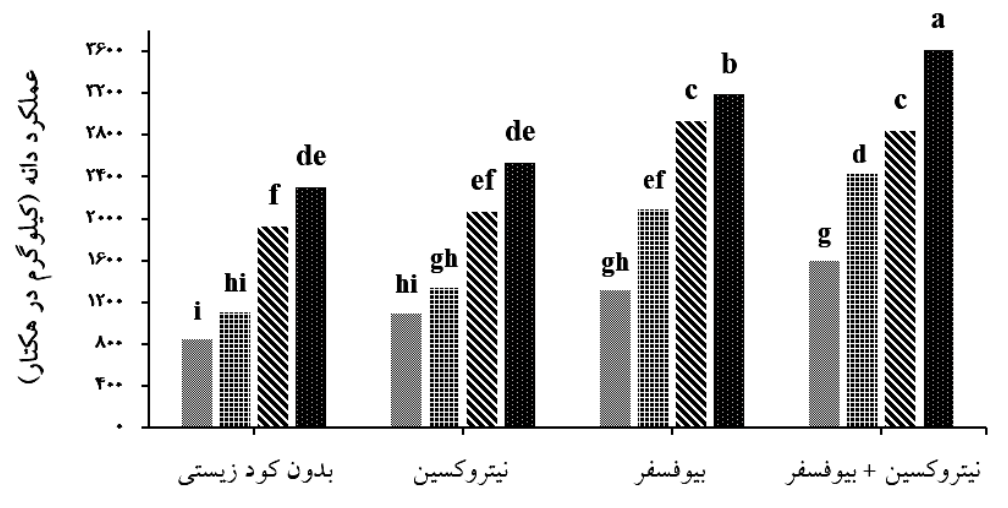

(الف)
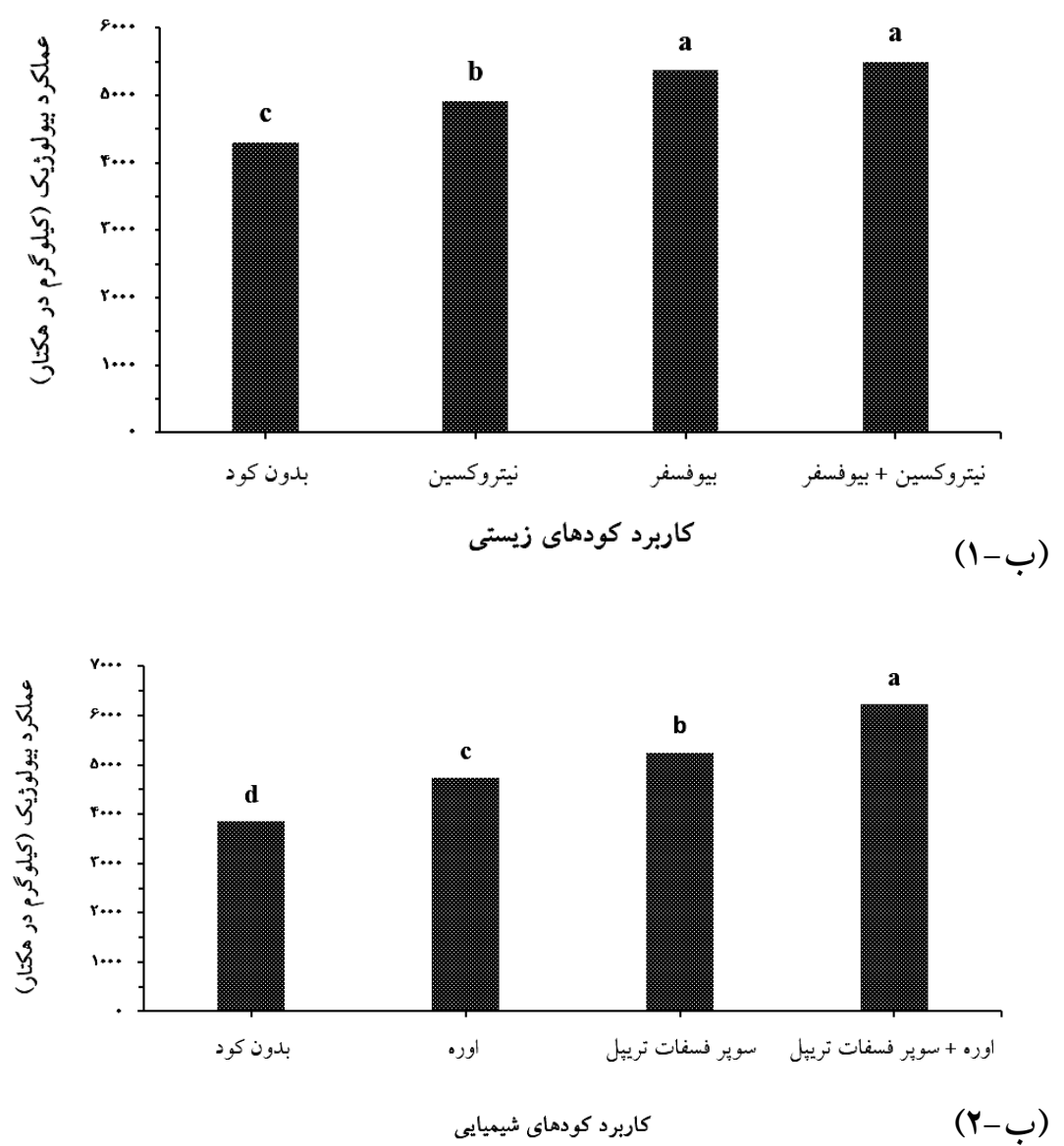

شكل fا. الف) اثر برهم كنش تيمارهاى كود شيميايى و كود زيستى بر عملكرد دانه كينوا رقم ساجاما، ب- () تأثير كودهاى زيستى و ب - r - كودهاى شيميايى بر عملكرد بيولوزيك كينوا رقم ساجاما

(ميانخينهاى داراى حروف مشترى در هر ستون مطابق آزمون LSD محافظت شده در سطح ينج درصد اختلاف معنىدار ندارند).

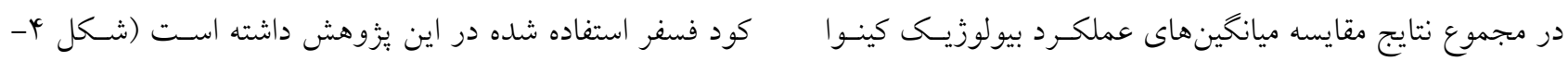

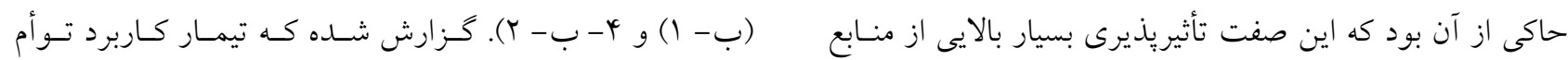




$$
\begin{aligned}
& \text { زيستى بهويزه در شـرايط كـاربرد تلفيقـى آنهـا، بـر عملكـــد و } \\
& \text { اجزاى عملكرد در كياه كينوا است. بهنحوى كه كاربرد كودهـاى }
\end{aligned}
$$

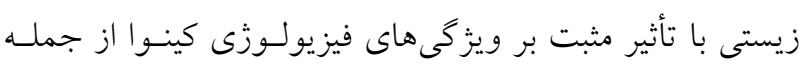

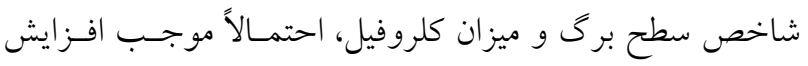

$$
\begin{aligned}
& \text { فتوسنتز و از اين طريق سبب افزايش عملكرد در اين كياه شـده } \\
& \text { است. اما از آنجايى كه تيمار تلفيق كودهاى شيميايى و كودهاى } \\
& \text { زيستى بيشترين تأثير را بر افزايش عملكرد كينوا داشت، مىتوان } \\
& \text { اظهار داشت كه كودهاى زيستى نيتروكسين و بيوفسفر، بهتنهايى } \\
& \text { قادر به تأمين كامل عناصر غذايى مورد نياز اين گياه نيستند ولى } \\
& \text { اگر همراه با كودهاى شيميايى مورد نياز، طبق نتايج آزمون خاك } \\
& \text { استعمال شوند، مىتوانند در بهبود و افزايش عملكرد كينوا مـؤثر } \\
& \text { واقع شوند. بنابراين با توجه به نتايج اين يزوهش كاربرد تلفيقى } \\
& \text { كودهاى زيستى نيتروكسين و بيوفسفر بههمراه مصرف كودهـاى } \\
& \text { شيميايى مورد نياز، مطابق نتايج آزمون خاك براى كشـت كينـوا } \\
& \text { در خاكها و شرايط آبوهوايى مشابه قابل توصيه است. }
\end{aligned}
$$$$
\text { كودهاى شيميايى و زيستى فسفر موجب افزايش معنسىدار وزن }
$$

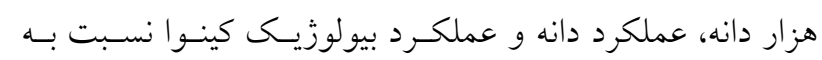$$
\text { تيمار شاهد شده است (4 (1). بهطور كلى مصسرف فسـفر سـبب }
$$$$
\text { افزايش در جذب مواد غذايى و فتوسنتز و حفـظ سـلامت گيـاه }
$$$$
\text { در طول دوره رشد شده و بههمـين دليـل انتقـال مـواد بـه دانـه }
$$$$
\text { بيشتر شده و افزايش عملكرد را بههمراه دارد ( آا). با توجه بـهـ }
$$

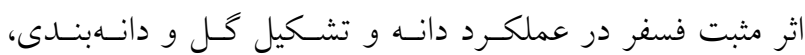$$
\text { مىتوان نتيجه گرفت كه تأمين فسفر كافى براى گياهـان زراعى }
$$$$
\text { يكى از راهكارهاى افزايش عملكرد بيولوزيك محسوب شــده و }
$$$$
\text { دليل ديخر را مىتوان به نقش بسيار مهم فسفر در تـأمين انـرزى }
$$$$
\text { (در ساختار ATP) دانست، زيــرا بــراى تثبـت انــرزى فراوانى }
$$

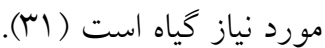$$
\text { نتيجه كيرى }
$$$$
\text { بهور كلى نتايج اين يزوهش نشاندهنده تأثير معنى دار كودهاى }
$$

\section{منابع مورد استفاده}

1. Abugoch, L. E. 2017. Quinoa (Chenopodium quinoa Willd.): Composition, chemistry, nutritional, and functional properties. Food and Nutrition Research 58: 1-31.

2. Awadalla, A. and A. S. M. Morsy. 2017. Influence of planting dates and Nitrogen fertilization on the performance of quinoa genotypes under Toshka conditions. Egyptian Journal of Agronomy 39(1): 27-40.

3. Basra, S. M. A., S. Iqbal and I. Afzal. 2014. Evaluating the response of Nitrogen application on growth, development and yield of quinoa genotypes. Journal of Agriculture and Biology 16: 886- 892.

4. Bagayoko, M. 2012. Effects of plant density, organic matter and Nitrogen rates on rice yields in the system of rice intensification (SRI) in the "office du niger" in Mali. Journal of Agricultural and Biological Science 7(8): 620-632.

5. Bilalis, D., I. Kakabouki, A. Karkanis, I. Travlos, V. Triantafyllidis and D. Hela. 2012. Seed and saponin production of organic quinoa (Chenopodium quinoa Willd.) for different tillage and fertilization. Notulae Botanicae Horti Agrobotanici Cluj-Napoca 40(1): 42-46.

6. Biglouie, M. H., M. H. Assimi and A. R. Jabbarzadeh. 2006. Effect of supplemental irrigation on yield and yield components of flue-cured tobacco. Iranian Journal of Field Crop Science 8(2): 184-200. (In Farsi).

7. Dadashzadeh, S., R. Seyed Sharifi and S. Farzaneh. 2018 Effects of bio-fertilizer and nano iron oxide on yield, chlorophyll content and modeling of some components of grain filling period of barley (Hordeum vulgare L.) under Salinity Stress Levels. Iranian Journal of Field Crops Research 16(2): 493-509. (In Farsi).

8. Ehteshami, S. M. R., M. R. Abbasi and K. Khavazi. 2013. Effect of Pseudomonas putida on yield and phosphorus uptake of three forage sorghum cultivars in Varamin. Soil Biology 1(2): 133-144. (In Farsi).

9. Fawy, H. A., F. Moharam, A. Hagab and R. Hagab. 2017. Effect of nitrogen fertilization and organic acids on grains productivity and biochemical contents of quinoa plant grown under soil conditions of Ras Sadersina. Egyptian Journal of Desert Research 67(1): 169-183.

10. Gang, Y. Q., Y. Jing, Y. Shao-n, F. Jian-rong, M. Jun-wei, S. Wan-chun, J. Li-na, W. Qiang and W. Jian-mei. 2013. Effects of nitrogen application level on rice nutrient uptake and ammonia volatilization. Rice Science 20(2): 139147.

11. Garcia, M., B. Condori and C. D. Castillo. 2015. Agroecological and agronomic cultural practices of quinoa in South America. Quinoa: Improvement and Sustainable Production 25-46. 
12. Geren, H. 2015. Effects of different nitrogen levels on the grain yield and some yield components of quinoa (Chenopodium quinoa Willd.) under mediterranean climatic conditions. Turkish Journal of Field Crops 20(1): 5964.

13. Ghimire, B., D. Timsina and J. Nepal. 2015. Analysis of chlorophyll content its correlation with yield attributing traits on early varieties of maize (Zea mays L.). Journal of Maize Research and Development 1(1): 134-145.

14. Gomaa, E. F. 2013. Effect of nitrogen, phosphorus and biofertilizers on quinoa plant. Journal of Applied Sciences Research 9(8): 5210- 5222.

15. Khorshidi, Y. R., M. R. Ardakani, M. R. Ramezanpour, K. Khavazi and K. Zargari. 2011. Response of yield and yield components of rice (Oryza sativa L.) to Pseudomonas flouresence and Azospirillum lipoferum under different nitrogen levels. American-Eurasian Journal of Agricultural and Environmental Sciences 10(3): 387-395.

16. Lichtenthder, H. K. 1987. Cholorophylls and carotenoids: pigments of photosynthetic biomembranes. Enzymology 148: 350- 382.

17. Mataei, S., R. Amirnia, M. Tajbakhsh and B. Abdollahi Mandulakani. 2014. Effects of iron, zinc, manganese, and method of their application on phonology, yield and grain quality of sweet corn. Journal of Crop Production and Processing 4(11): 231-240.

18. Mosavi, S. B., A. A. Jafarzadeh, M. R. Neishabouri, S. Ostan and V. Feiziasl. 2009. Rye green manure along with nitrogen fertilizer application increases wheat (Triticum aestivum L.) production under dryland condition. International Journal of Agriculture Research 4(6): 204-212.

19. Panayiota, P., I. Kakabouki, I. Travlos and D. Bilalis 2014. Effect of fertilization on yield and quality of biomass of quinoa (Chenopodium quinoa Willd.) and green amaranth (Amaranthus retroflexus L.). Notulae Botanicae Horti Agrobotanici Cluj-Napoca 71(2):288-294.

20. Rezaei Chiyaneh, E., A. Pirzad and A. Farjami. 2014. Effect of nitrogen, phosphorus and sulfur supplier bacteria on seed yield and essential oil of cumin (Cuminum cyminum L.). Journal of Sustainable Agriculture and Production Science 24(4): 72-83. (In Farsi).

21. Roesty, D., R. Gaur and B. N. Johri. 2006. Plant growth stage, fertilizer management and bioinoculation of arbuscular mycorrhizal fungi and plant growth promoting rhizobactria affect the rhizobactrial community structure in rain-fed wheat fields. Journal of Soil Biology 38: 1111-1120.

22. Sadeghi, S., G. H. Heidari and Y. Sohrabi. 2015. Effect of biological fertilizer and fertilization management on some growth indices of two maize varieties. Journal of Agriculture Science and Sustainable Production 25(3): 4360. (In Farsi).

23. Sa-nguansak, T. 2004. Effect of nitrogen fertilizer on nitrogen assimilation and seed quality of amaranth (Amaranthus spp.) and quinoa (Chenopodium quinoa Willd.). MSc thesis. Georg-August-University. Phayao, Thailand.

24. Shams, A. S. 2012. Response of quinoa to nitrogen fertilizer rates under sandy soil conditions. In: Proceeding of $13^{\text {th }}$ International Conference of Agronomy Sciences. Benha, Egypt. pp.195-205.

25. Singh, D., S. Chand, M. Anvar and D. Patra. 2003. Effect of organic and inorganic amendment on growth and nutrient accumulation by isabgol (Plantago ovata) in sodic soil under greenhouse conditions. Journal of Medicinal and Aromatic Plants 25: 414- 419.

26. Soleimanzadeh, H., D. Habibi, M. R. Ardakani, F. Paknejad and F. Rejali. 2010. Response of sunflower (Helianthus annuus L.) to inoculation with Azotobacter under different nitrogen levels. American-Eurasian Journal of Agricultural and Environmental Sciences 7(3): 265-268.

27. Sonmez, C. 2018. Effect of phosphorus fertilizer on some yield componenets and quality of different Anise (Pimpinella anisum L.) populations. Journal of Turk Field Crops 23(2): 100-106.

28. Tanwar, S. P. S., G. L. Sharma and M. S. Chahar. 2002. Effects of phosphorus and biofertilizers on growth and productivity of black gram. Annals of Agricultural Sciences 23(3): 491-495.

29. Telahigue, D., L. B. Yahia, F. Aljane, K. Belhouchett and L. Toumi. 2017. Grain yield, biomass productivity and water use efficiency in quinoa (Chenopodium quinoa Willd.). under drought stress. Science of Food and Agriculture 1: 222- 232 .

30. Vance, C. P. 2011. Symbiotic nitrogen fixation and phosphorus acquisition. Plant nutrition in world of declining renewable resources. Journal of Plant Physiology 127: 390-397.

31. Wu, S. C., Z. H. Cao, Z. G. Li, K. C. Cheung and M. H. Wong. 2005. Effects of biofertilizers containing N-fixer, P and K. solubilizer and AM fungi on maize growth: a greenhouse trial. Geoderma 125: 155-166.

32. Yadav, R. D., G. L. Keshwa and S. S. Yadva. 2002. Effect of integrated use of urea and sulphur on growth and yield of Isabgol (Plantago ovata). Journal of Medicinal and Aromatic 25: 668-671.

33. Yang, Y. C., M. Zhang, L. Zheng, D. D. Cheng, M. Liu and Y. Q. Geng. 2011 Controlled release urea improved nitrogen use efficiency, yield, and quality of wheat. Agronomy Journal 103(2): 479-485.

34. Yasari, E. and A. M. Patwardhan. 2007. Effect of Aztobacter and Azospirillum inoculations and chemical fertilizers 
on growth and productivity of canola. Asian Journal of Plant Sciences 6(1): 77-82.

35. Zayed, B. A., W. M. Elkhoby, A. K. Salem, M. Ceesay and N. T. Uphoff. 2013. Effect of integrated nitrogen fertilizer on wheat productivity and soil fertility under saline soil conditions. Journal of Plant Biology Research 2(1): 14-24. 


\title{
Effect of Chemical and Biological Fertilizers on Some Physiological Traits, Yield Components and Yield of Quinoa Plant
}

\author{
M. Amiryousefi ${ }^{1}$, M. R. Tadayon ${ }^{2 *}$ and R. Ebrahimi ${ }^{3}$
}

(Received: April 20-2019; Accepted: July 30-2019)

\begin{abstract}
In order to investigate the effects of solitary and combined application of chemical and biological fertilizers on the yield and yield components of quinoa plant, a factorial experiment was conducted based on randomized complete block design with three replications in Dastgerd (Borkhar), Isfahan, central Iran, during the 2017-2018 growing season. Experimental factors included four levels of Chemical fertilizers [control, urea, triple superphosphate (TSP), and combined urea + TSP fertilizers] and bio-fertilizers at four levels (no inoculation, and inoculations with nitroxin, biophosphorus, and combined nitroxin + biophosphorus). Results showed that the interaction effects of chemical and biological fertilizers on leaf area index, grain yield, and yield components (including number of panicles per $\mathrm{m}^{2}$, number of grains per panicle, and 1000-grain weight) of quinoa plant were significant at $1 \%$ probability level. Combined application of urea and TSP fertilizers had the highest impact on the biological yield. Overall, the results showed that plant height, chlorophyll content and the number of panicles per $\mathrm{m}^{2}$ were significantly influenced by nitrogen sources of fertilizers used in this study. The phosphorus fertilizer sources had the highest effects on leaf area index, number of grains per panicle, 1000-grain weight, grain yield, and biological yield, which can be attributed to the greater impact of nitrogen on the increase of prolific panicles and to the marked role of phosphorus in both flower and grain formation. The integrated application of biofertilizers and all of the examined chemical fertilizers treatments increased the yield of quinoa plant compared to the control. Therefore, the application of biofertilizers as supplements can be introduced as a practical approach for optimal and balanced use of chemical fertilizers in order to achieve sustainable agriculture goals in quinoa cultivation.
\end{abstract}

Keywords: Nitrogen, Phosphorus, Leaf area index, Biological yield, Quinoa

1,2. Ph.D. Student and Professor, Respectively, Department of Agronomy, Faculty of Agriculture, Shahrekord University, Shahrekord, Iran.

3. Professor, Department of Mechanical Engineering of Biosystems, Faculty of Agriculture, Shahrekord University, Shahrekord, Iran.

*: Corresponding Author, Email: mrtadayon@yahoo.com 